\title{
Sonic Hedgehog Regulates Integrin Activity, Cadherin Contacts, and Cell Polarity to Orchestrate Neural Tube Morphogenesis
}

\author{
Claire Fournier-Thibault, ${ }^{1,2}$ Cédrine Blavet, ${ }^{1,2}$ Artem Jarov, ${ }^{1,2}$ Fernanda Bajanca, ${ }^{3,4}$ Sólveig Thorsteinsdóttir, ${ }^{3,4}$ \\ and Jean-Loup Duband ${ }^{1,2}$ \\ ${ }^{1}$ Université Pierre et Marie Curie-Paris 6, Laboratoire de Biologie du Développement, and ${ }^{2}$ Centre National de la Recherche Scientifique, Laboratoire de \\ Biologie du Développement, 75005 Paris, France, ${ }^{3}$ Departamento de Biologia Animal, Centro de Biologia Ambiental, Faculdade de Ciências, Universidade \\ de Lisboa, 1749-016 Lisboa, Portugal, and "Instituto Gulbenkian de Ciência, 2781-901 Oeiras, Portugal
}

In vertebrates, the embryonic nervous system is shaped and patterned by a series of temporally and spatially regulated cell divisions, cell specifications, and cell adhesions and movements. Morphogens of the Hedgehog, Wnt, and bone morphogenetic protein families have been shown to play a crucial role in the control of cell division and specification in the trunk neural tube, but their possible implication in the regulation of adhesive events has been poorly documented. In the present study, we demonstrate that Sonic hedgehog regulates neural epithelial cell adhesion and polarity through regulation of integrin activity, cadherin cell-cell contact, and cell polarity genes in immature neural epithelial cells before the specification of neuronal cells. We propose that Sonic hedgehog orchestrates neural tube morphogenesis by coordinating adhesive and motility events with cell proliferation and differentiation.

\section{Introduction}

Development of the embryonic nervous system requires changes in cell fate, cell cycle, and cell movement, which are governed by pathways that signal to the nucleus, inducing gene transcription, as well as signaling that impacts the cytoskeleton. Understanding how these pathways are integrated is essential to a comprehensive knowledge of the formation of the nervous system.

In vertebrates, neurulation proceeds as a series of steps by which the neural plate is shaped into a tube that extends along the anteroposterior axis (Colas and Schoenwolf, 2001). Cell division transforms the neural plate from a simple cuboidal into a pseudostratified epithelium in which neural epithelial (NE) cells contact both the basal and the luminal sides. Mitosis occurs apically and nuclei move toward the basal side where NE cells either reenter the cell cycle or undergo differentiation (Wilcock et al., 2007), allowing the positioning of progenitors that give rise to the spinal cord. Patterning of the neural tube occurs along its dorsoventral axis with motor neurons differentiating ventrally and sensory neurons and neural crest (NC) cells dorsally (Briscoe and

Received April 28, 2009; revised July 17, 2009; accepted Aug. 1, 2009.

This work was supported by Centre National de la Recherche Scientifique, Université Pierre et Marie Curie-Paris 6, and Association pour la Recherche contre le Cancer Grants 5590 and 3524. F.B. and S.T. were supported by Fundação para a Ciência e a Tecnologia/FEDER via POCTI/BCI/47681/2002 and the FP6/European Union Network of Excellence "Cells into Organs." We thank our colleagues for generously providing constructs, probes, and antibodies.

Correspondence should be addressed to either Claire Fournier-Thibault or Jean-Loup Duband, Université Pierre et Marie Curie-Paris 6, Centre National de la Recherche Scientifique, Laboratoire de Biologie du Développement, 75005 Paris, France. E-mail: cfournie@snv.jussieu.fr or jean-loup.duband@upmc.fr.

A. Jarov's present address: Roche, Shire Park, Welwyn Garden City AL7 1TW, UK.

F. Bajanca's present address: Randall Division for Cell and Molecular Biophysics, Third Floor North, New Hunt's House, Guy's Campus, King's College London, London SE1 1UL, UK.

D01:10.1523/JNEUROSCI.2003-09.2009

Copyright $\odot 2009$ Society for Neuroscience ～0270-6474/09/2912506-15\$15.00/0
Novitch, 2008). Once committed, neural progenitors become located basally while NC cells, unlike other neural cells, disperse through the adjacent tissues.

Considerable progress has been made in deciphering the signals that regulate neural tube morphogenesis. Signaling molecules of the Hedgehog $(\mathrm{HH})$, Wnt, and bone morphogenetic protein (BMP) families have been implicated in the generation of neural progenitors. Dorsally, BMPs specify sensory cells and NC cells (Liem et al., 1997). Ventrally, Sonic hedgehog (SHH) drives the position and identity of ventral neurons (Briscoe and Novitch, 2008). In addition to BMPs, Wnt proteins also regulate dorsal progenitor proliferation and identity (Muroyama et al., 2002). Recently, evidence have been obtained showing that $\mathrm{SHH}$ also influences NE cell proliferation and survival (Cayuso et al., 2006), suggesting that gradients emanating from opposite poles in the neural tube, BMPs/Wnts dorsally and SHH ventrally, simultaneously control neural growth and patterning.

Coordinated morphogenesis of the neural tube would imply that morphogen activities extend to the control of NE cell adhesion, polarity, and movement, but data are still sketchy. An integrated control has only been provided for NC cells in which the activities of Wnt1, BMP4, and its antagonist Noggin have been found to orchestrate $\mathrm{NC}$ cell adhesion, proliferation, and specification during delamination (Kalcheim and Burstyn-Cohen, 2005; Duband, 2006). Conversely, in vitro, SHH has been shown to alter NE and NC cell adhesion properties, causing repression of NC cell delamination (Testaz et al., 2001), but the importance of this effect in neural tube morphogenesis has not been investigated. In this study, we assess the role of morphogens in the regulation of adhesive and migratory properties of NE cells by misexpressing Shh, its antagonist Hedgehog-interacting protein 

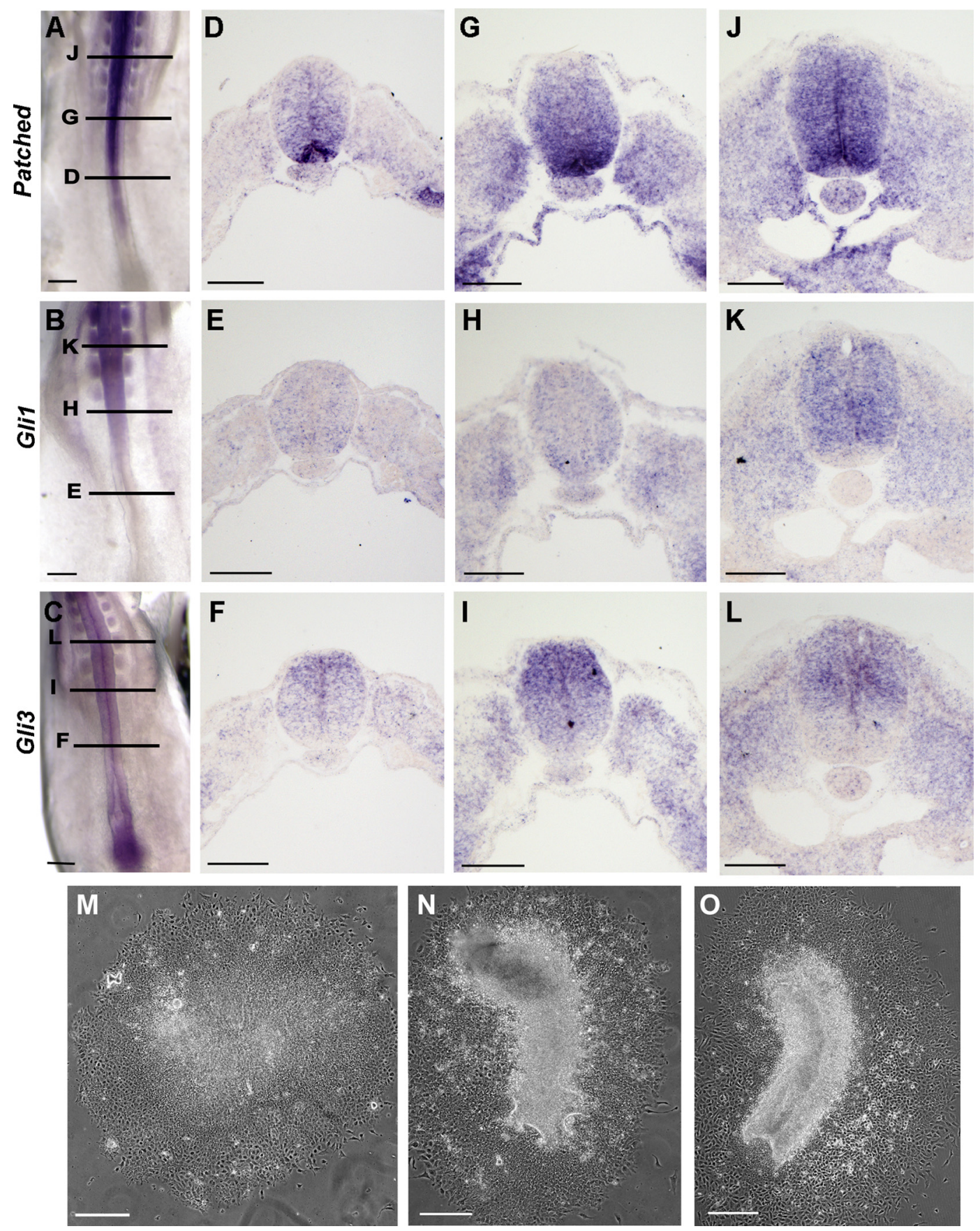

Figure 1. Propagation of Shh signal correlates with changes in NE cell adhesion properties. $\boldsymbol{A}-\boldsymbol{C}$, Whole-mount in situ hybridization on 20 somite stage embryos for Ptc 1 ( $\boldsymbol{A}$ ), Gli $(\boldsymbol{B})$, and $G$ li3 ( $\boldsymbol{C}$. $\boldsymbol{D}-\boldsymbol{L}$, Transverse sections at the indicated levels of the neural axis showing expression of $\operatorname{Ptc} \boldsymbol{C}(\boldsymbol{D}, \boldsymbol{G}, \boldsymbol{J}), \boldsymbol{G l i}(\boldsymbol{E}, \boldsymbol{H}, \boldsymbol{K})$, and $G l i 3(\boldsymbol{F}, \boldsymbol{I}, \boldsymbol{L})$, and revealing the progressive diffusion of $\operatorname{Shh}$ signal toward the dorsal part of the neural tube. $\boldsymbol{M} \mathbf{- O}$, Phase contrast views after $24 \mathrm{~h}$ of culture of neural explants at levels corresponding to the caudal unsegmented mesoderm $(\boldsymbol{M})$, rostral unsegmented mesoderm $(\boldsymbol{N})$, and last-formed somites $(\boldsymbol{O})$, showing gradual restriction of NE cell capacity to spread into a flat monolayer. At the somite level, only NC cells disperse onto the FN substratum. Scale bars: $A-C, 200 \mu \mathrm{m} ; \boldsymbol{D}-J, 150 \mu \mathrm{m} ; \boldsymbol{M}-\mathbf{0}, 100 \mu \mathrm{m}$.

(Hip1), and Bmp4 in the avian embryonic neural tube. We provide evidence that $S h$ orchestrates NE cell adhesion and polarity through regulation of integrin activity, cadherin contacts, and cell polarity genes, leading to a coordinated regulation of adhesive capacities of NE cells during development.

\section{Materials and Methods}

Probes and antibodies. The following probes were used: Ptcl, Gli1, and Gli3 from C. Tabin (Harvard Medical School, Boston, MA), Pax3 from P. Gruss (Max Planck Institute, Göttingen, Germany), Cad6B from M. Takeichi (RIKEN Center for Developmental Biology, Kobe, Japan), Daam1 from Y.
Kida (Tohoku University, Sendai, Japan), RhoB from I. de Curtis (Department of Biological and Technological Research, Milan, Italy), and Hip 1 from A. McMahon (Harvard University, Cambridge, MA). The HNK1 mAb has been described previously (Tucker et al., 1984). The antibodies to the $\beta 1$ integrin subunit and to laminin were from K. Yamada (National Institutes of Health-National Institute of Drug Research, Bethesda, MD) and SigmaAldrich, respectively. The GoH3 rat $\mathrm{mAb}$ to the $\alpha 6$ integrin subunit and the JsE3 control rat $\mathrm{mAb}$ were from A. Sonnenberg (Netherlands Cancer Institute, Amsterdam, The Netherlands). The phosphohistone H3 (PH3) antibody was from Millipore, BEN and PAX3 mAbs were from the Developmental Studies Hybridoma Bank (University of Iowa), the TASC 

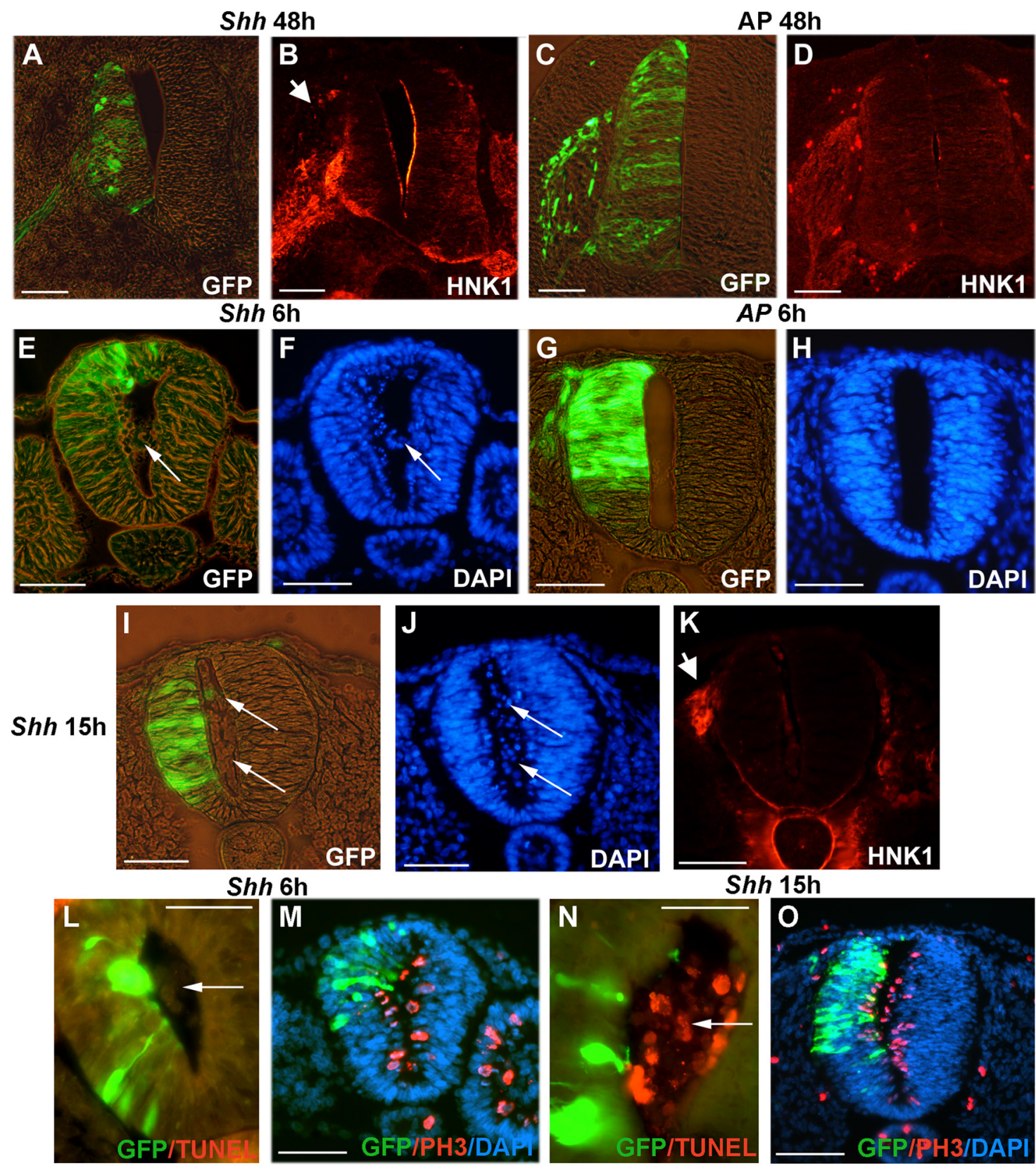

P Number of cells in the lumen of neural tube/section

Q Number of PH3 cells/section
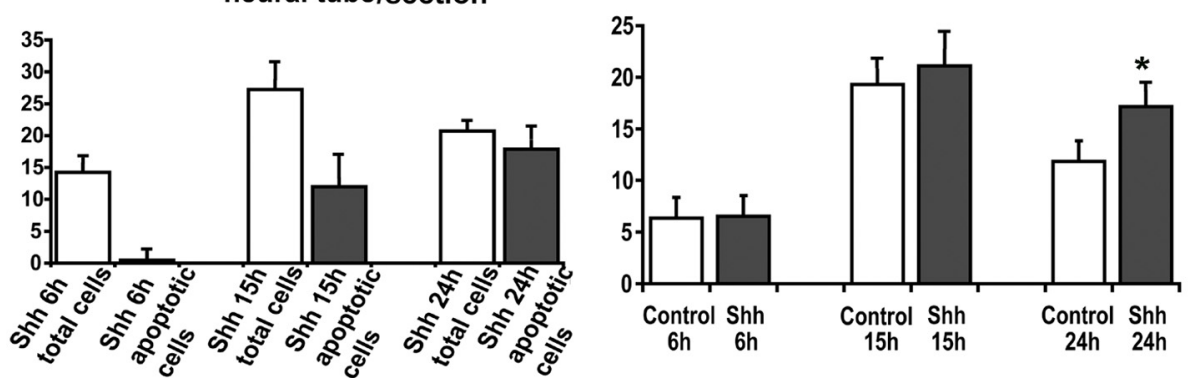

Figure 2. Shhmisexpression provokesmorphological defects in theneural tubeas a consequence of NEcell extrusion into the lumen. $\boldsymbol{A}-\boldsymbol{D}, \mathrm{Morphology}$ of $S h h-(\boldsymbol{A}, \boldsymbol{B})(n=18)$ and $A P-(\boldsymbol{C}, \boldsymbol{D})(n=5)$ electroporated neural tubes at $48 \mathrm{hpe}$. $\boldsymbol{E}-\mathbf{0}$, Morphology of neural tubes electroporated with Shh at $6 \mathrm{hpe}(\boldsymbol{E}, \boldsymbol{F}, \mathbf{L}, \boldsymbol{M})(n=25)$ and at $15 \mathrm{hpe}(\boldsymbol{I}-\boldsymbol{K}, \boldsymbol{N}, \mathbf{0})(n=23)$, showing massive cell extrusion into the lumen of the neural tube $(\boldsymbol{E}, \boldsymbol{F}, \boldsymbol{I}, \boldsymbol{J}$, arrows $)$. Control, $A$ P-electroporated neural tubes $(\boldsymbol{G}, \boldsymbol{H})(n=6)$ show no extruded cells at $6 \mathrm{hpe}$. TUNEL at $6 \mathrm{hpe}(\boldsymbol{L})(n=6)$ and $15 \mathrm{hpe}(\boldsymbol{N})(n=6)$ reveal apoptotic cells only in cells sextruded in the lumen after $15 \mathrm{hpe}(\boldsymbol{L}, \boldsymbol{N}$, arrows). PH3 immunoreactivity shows proliferation in neural tubes electroporated at $6 \mathrm{hpe}(\boldsymbol{M})(n=6)$ and at $15 \mathrm{hpe}(\boldsymbol{O})(n=5)$. HNK1 staining at $15 \mathrm{hpe}(\boldsymbol{K})(n=23)$ and at $48 \mathrm{hpe}(\boldsymbol{B})(n=18)(\boldsymbol{D})(n=5)$ illustrates the defect in NCcell migration after Shh misexpression, leading to reduction of the size of dorsal root ganglion ( $\boldsymbol{B}, \boldsymbol{K}$, shortarrows). Scale bars, $50 \mu \mathrm{m}$. $\boldsymbol{P}, \mathbf{Q}$ uantitative analysis of TUNEL-positive cells compared with the total cell number into the lumen of the electroporated neural tube. Apoptosis only occurred from $15 \mathrm{hpe} \mathrm{indicating} \mathrm{anoikis} \mathrm{as} \mathrm{a} \mathrm{result} \mathrm{of} \mathrm{cell} \mathrm{extrusion.} \mathrm{Q,} \mathrm{Quantitative} \mathrm{analysis} \mathrm{of} \mathrm{PH3-positive} \mathrm{cells} \mathrm{in} \mathrm{electroporated} \mathrm{(Shh)} \mathrm{and} \mathrm{nonelectroporated}$ (control) sides of the neural tube. The number of PH3 cells was only significantly increased in the transfected side from $24 \mathrm{hpe}$ on. Errors bars indicate SD. ${ }^{*} p<0.05$. 

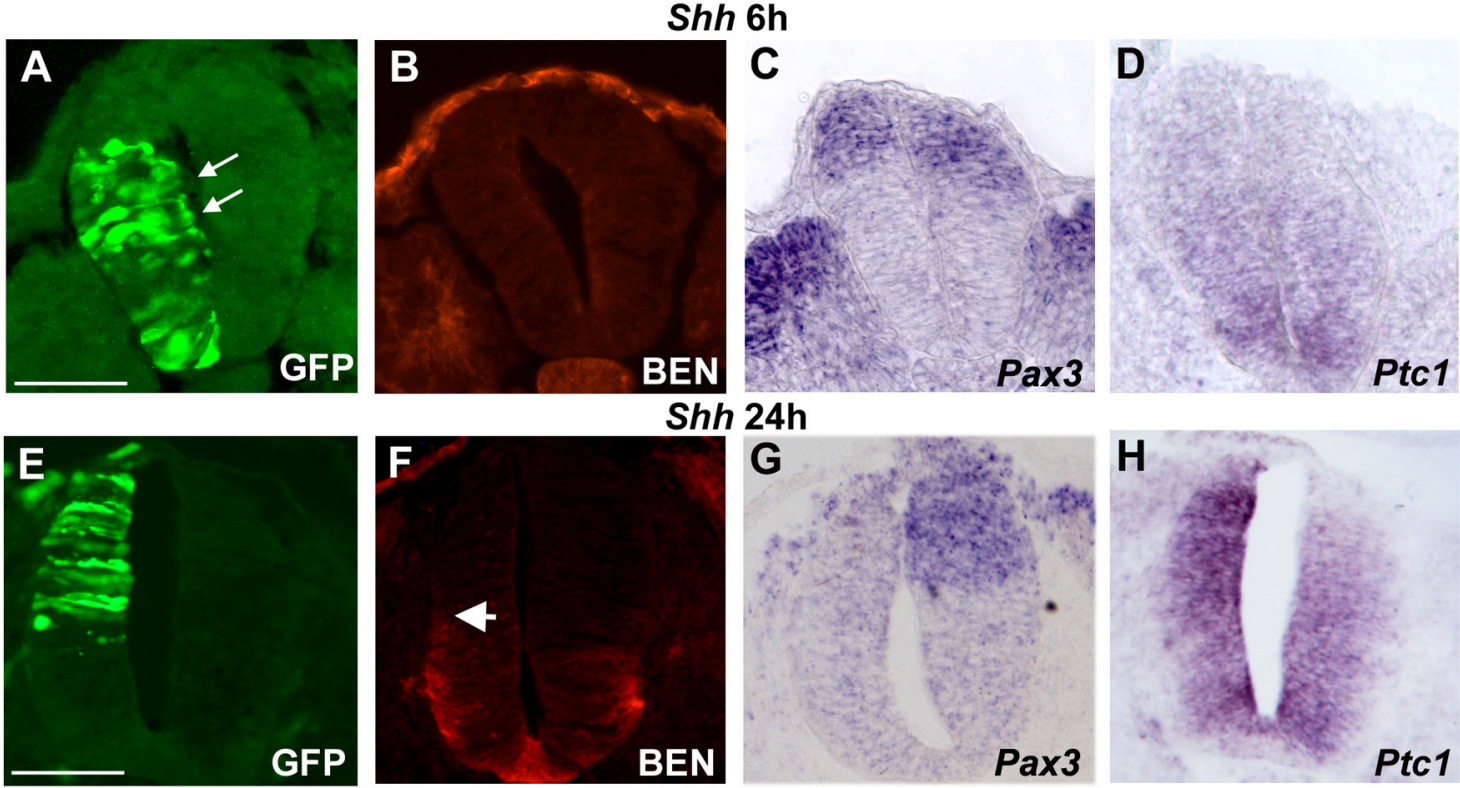

\section{Shh 48h}
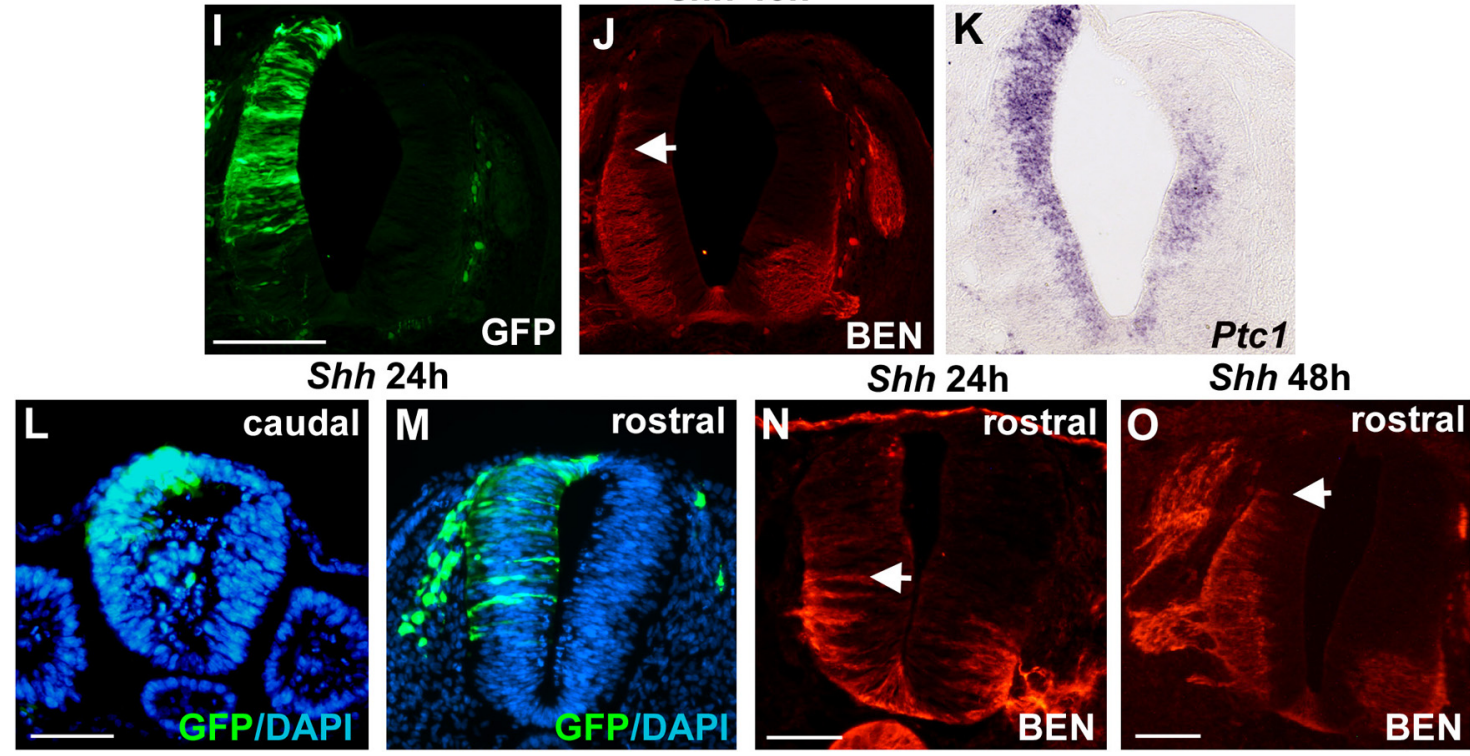

Figure 3. Morphological defects in Shh-misexpressing neural tubes occur before and independently of its dorsoventral patterning. $A-K$, Expression of GFP $(A, E, I)$ and of markers of cell lineages $(\operatorname{Pax} 3)(\boldsymbol{C}, \boldsymbol{G})$, cell differentiation (BEN) $(\boldsymbol{B}, \boldsymbol{F}, \boldsymbol{J})$, and Shh signaling $(\operatorname{Ptc} 1)(\boldsymbol{D}, \boldsymbol{H}, \boldsymbol{K})$ on serial sections of Shh-electroporated neural tubes at 6 hpe $(\boldsymbol{A}-\boldsymbol{D}), 24 \mathrm{hpe}(\boldsymbol{E}-\boldsymbol{H})$, and $48 \mathrm{hpe}(\boldsymbol{I}-\boldsymbol{K})$. The arrows in $\boldsymbol{F}$ and $\boldsymbol{I}$ point at ectopic motor neuron progenitors. $\boldsymbol{L}-\mathbf{0}$, Morphology of neural tubes electroporated with Shh at the level of the caudal unsegmented mesoderm $(\boldsymbol{L})$ or of the last somites $(\boldsymbol{M}-\mathbf{0})$. When electroporated at rostral levels, Shh shows no effect on the neural tube morphology $(\boldsymbol{M})$, although it retains its ability to induce ectopic motor neurons at $24 \mathrm{hpe}(\boldsymbol{N})$ and $48 \mathrm{hpe}(\boldsymbol{O})$, as shown by BEN staining. Scale bars, $50 \mu \mathrm{m}$.

mAb was from Millipore Bioscience Research Reagents, and rhodaminephalloidin was from Sigma-Aldrich. The 5E1, APG6, and ACD1 mAbs to SHH were from L. Ling (Biogen).

In ovo electroporation. Chick and quail eggs were from commercial sources. Constructs for electroporation were mouse Shh cDNA in pRK5 from C.-M. Fan (Carnegie Institute of Washington, Baltimore, MD), AP cDNA in pcDNA3 from T. Jaffredo (Université Pierre et Marie Curie, Paris, France), mouse BMP4 cDNA in pCAFP-IRES from I. Palmeirim (University of Minho, Brafa, Portugal), a secreted form of mouse Hipl in pcDNA3 from A. McMahon (Harvard University, Cambridge, MA), and EGFP-N1 from Clontech. Shh, Hip1, or AP cDNAs at $0.8 \mu \mathrm{g} / \mu \mathrm{l}$ with green fluorescent protein (GFP) cDNA at $0.2 \mu \mathrm{g} / \mu \mathrm{l}$ or BMP4-GFP alone at $0.8 \mu \mathrm{g} / \mu \mathrm{l}$ were injected into the lumen of the neural tube of $15-25$ somite stage chick embryos. Electrodes were applied on either side of the trunk and five square pulses ( $25 \mathrm{~V}, 50 \mathrm{~ms}$ length) were delivered. Eggs were reincubated for up to $48 \mathrm{~h}$ postelectroporation (hpe). For in vitro studies, electroporations were performed on quail embryos as in chicks, except that pulses were delivered bilaterally to electroporate both sides of the neural tube. Eggs were reincubated for $4 \mathrm{~h}$, the embryos were dissected out, and the electroporated neural tubes expressing GFP were explanted in culture. For experiments using blocking antibodies, purified Igs against $\mathrm{SHH}$ protein were injected into the lumen of the neural tube of 15 somite stage embryos $(0.4 \mu \mathrm{g} / \mu \mathrm{l}$ for $5 \mathrm{E} 1 ; 0.2 \mu \mathrm{g} / \mu \mathrm{l}$ for APG6 and $\mathrm{ACD} 1$ ), and eggs were reincubated up to $18 \mathrm{~h}$. In some cases, embryos were simultaneously electroporated with GFP cDNA to visualize individual NE cells. For PMA treatment, chick embryos were screened for GFP expression at 4 hpe and $100 \mathrm{ng} / \mathrm{ml} \mathrm{PMA} \mathrm{(Calbiochem)} \mathrm{was} \mathrm{injected} \mathrm{into}$ the lumen of the neural tube.

Culture of explants and cell adhesion assays. Cultures of quail neural primordial or of trunk portions from embryonic day 9.5 (E9.5) mouse embryos were performed as described previously (Duband et al., 1995; Bajanca et al., 2006). Assays for cellular adhesion were performed as 
$4 h$
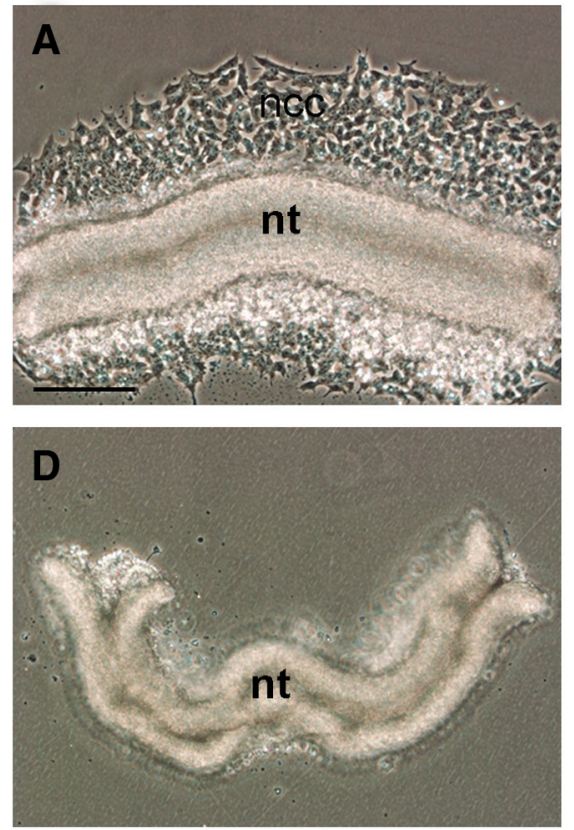

G
Neural tube surface $(x 0.1 \mathrm{~mm} 2)$

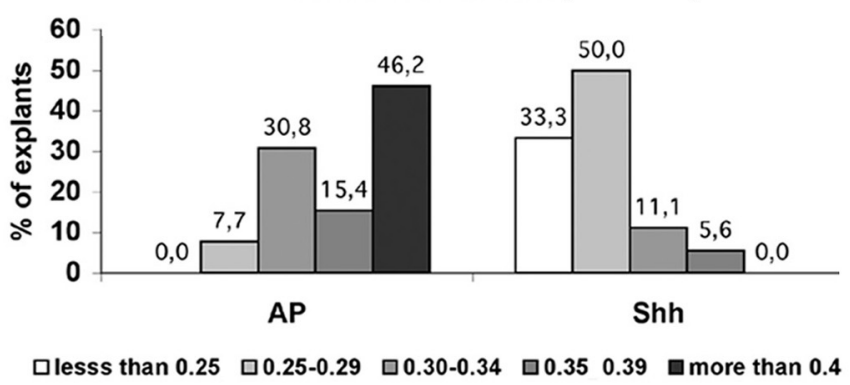

$18 \mathrm{~h}$
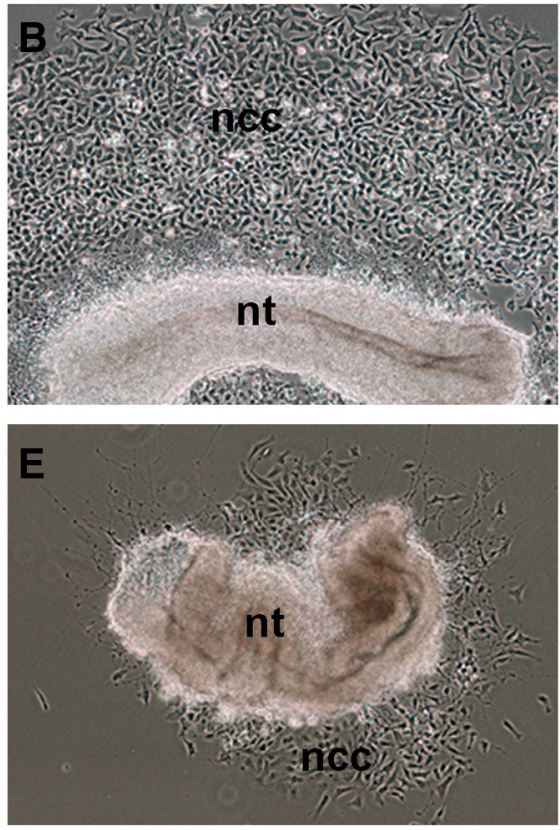

$18 \mathrm{~h}$
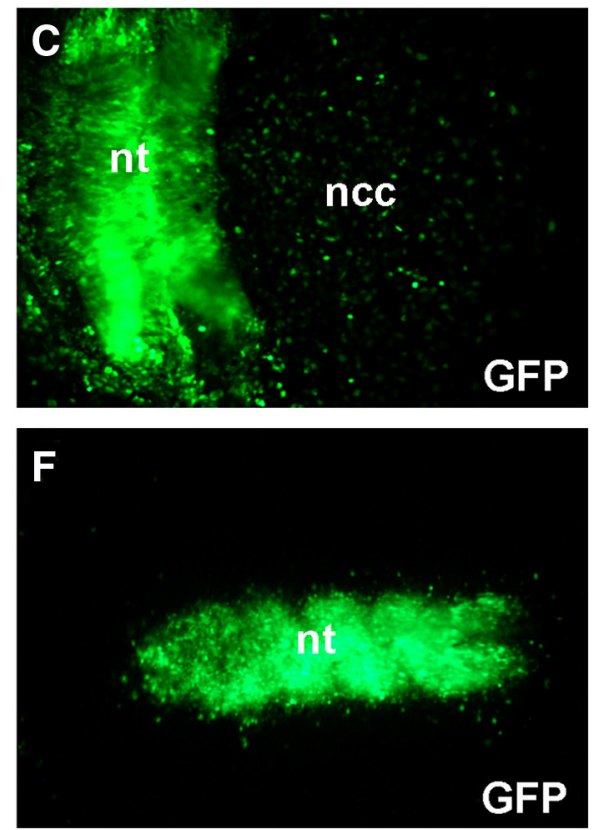

H

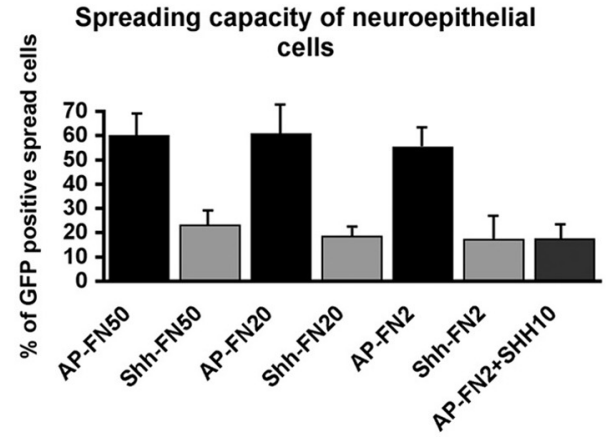

Figure 4. Shh overexpression causes inhibition of NE and NC cell substratum adhesion. $\boldsymbol{A}-\boldsymbol{F}$, Phase contrast $(\boldsymbol{A}, \boldsymbol{B}, \boldsymbol{D}, \boldsymbol{E})$ or GFP $(\boldsymbol{C}, \boldsymbol{F})$ views of $A P-(\boldsymbol{A}-\boldsymbol{C})(n=23$ of 29$)$ and $\operatorname{Shh}-(\boldsymbol{D}-\boldsymbol{F})(n=23$ of 33) electroporated neural tubes cultured for $4(\boldsymbol{A}, \boldsymbol{D})$ and $18 \mathrm{~h}(\boldsymbol{B}, \boldsymbol{C}, \boldsymbol{E}, \boldsymbol{F})$, showing neural tube (nt) compaction and reduction of migrating NC cells (ncc) in Shh-expressing explants. $\boldsymbol{G}$, Surface of $A P$ - and Shh-electroporated explants after $18 \mathrm{~h}$ in culture. Data are shown as a distribution of the neural tube explants as a function of their overall surface. $\boldsymbol{H}$, Spreading capacity (mean \pm SD) of GFP-positive NE cells on FN at 2, 20, and $50 \mu \mathrm{g} / \mathrm{ml}$ (AP-FN2, 20 and 50; Shh-FN2, 20 and 50; $n=24)$. Spreading of AP-electroporated cells on FN (2 $\mu \mathrm{g} / \mathrm{ml})$ in the presence of SHH (10 $\mu \mathrm{g} / \mathrm{ml})$ adsorbed onto the substratum (AP-FN2+SHH10) is shown for reference (Jarov et al., 2003). Scale bars: $\boldsymbol{A}-\boldsymbol{F}, 100 \mu \mathrm{m}$.

described previously (Jarov et al., 2003) using NE cells collected from GFP-positive neural tubes. Spread GFP-positive cells were counted and results were expressed as the percentage of spread cells in relation to the total number of GFP-positive cells.

Immunocytochemistry and in situ hybridization. Chick and mouse embryos were fixed, sectioned at $10-15 \mu \mathrm{m}$, and processed for immunocytochemistry or in situ hybridization as described previously (FournierThibault et al., 1999; Bajanca et al., 2004). Cultures of neural primordial were fixed in $3.7 \%$ formaldehyde for $30 \mathrm{~min}$ and permeabilized in $0.1 \%$ Triton X-100. Immunolabelings were performed using secondary antibodies conjugated to Alexa Fluor 488, 555, or 568 (Invitrogen). Nuclei were visualized with DAPI $\left(4^{\prime}, 6^{\prime}\right.$-diamidino-2-phenylindole) (SigmaAldrich) and GFP using mAb anti-GFP (Roche). Apoptosis was detected using terminal deoxynucleotidyl transferase-mediated biotinylated UTP nick end labeling (TUNEL) with Roche cell death detection kit.

\section{Results}

Shh signals correlate with changes in NE cell adhesion properties during neural tube morphogenesis

To determine whether $\mathrm{SHH}$ is a candidate for regulating cell adhesion during neural tube development, we first analyzed propagation of its signal in relation with putative changes in NE cell adhesion properties along the caudorostral axis of 15-25 somite avian embryos. Propagation of Shh signal was appreciated by analyzing expression pattern of its targets [e.g., the Patched1 (Ptc1) receptor and the Gli1 and Gli3 transcription factors]. Gli1 is induced by Shh and acts as an activator of its target genes, whereas Gli3 functions as a repressor to inhibit their expression (Ingham and McMahon, 2001; Stamataki et al., 2005). Cell-cell and cell-matrix adhesion within the neural tube was assessed by explanting neural tube in vitro over a fibronectin (FN) substratum. Although Shh was expressed evenly throughout the trunk region (data not shown), its signaling activity increased along the caudorostral neuraxis as revealed by expression patterns of Ptc1, Gli1, and Gli3 (Fig. $1 A-C$ ). Shh signal was faint and limited to the ventral neural tube at the level of the caudal unsegmented mesoderm (Fig. 1D-F). It increased significantly first in the ventral neural tube at the level of the rostral unsegmented mesoderm (Fig. $1 G-I$ ) and became intense almost throughout the ventrodorsal axis at the somite level (Fig. $1 J-L$ ). Propagation of Shh activity along the ventrodorsal axis of the neural tube matched the progressive changes in the adhesive properties of NE cells 

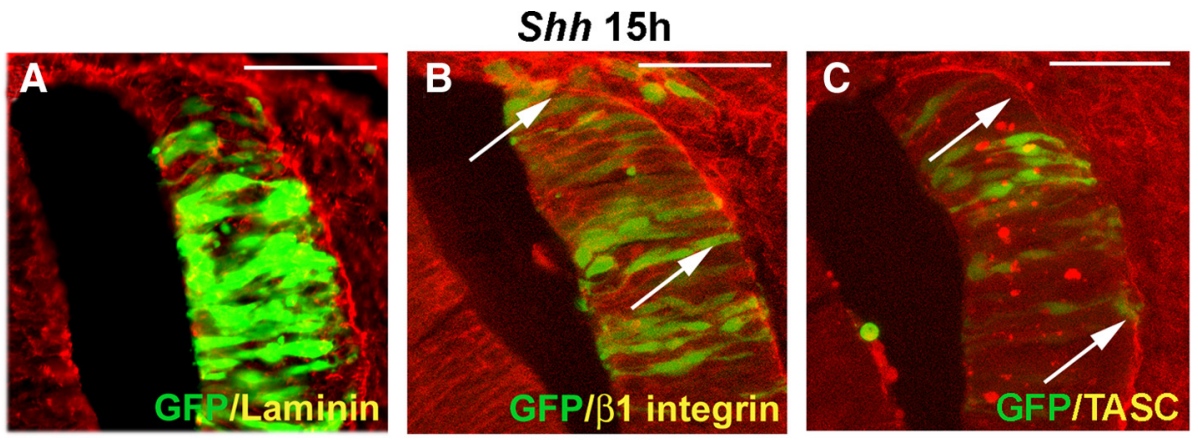

\section{Shh 15h}
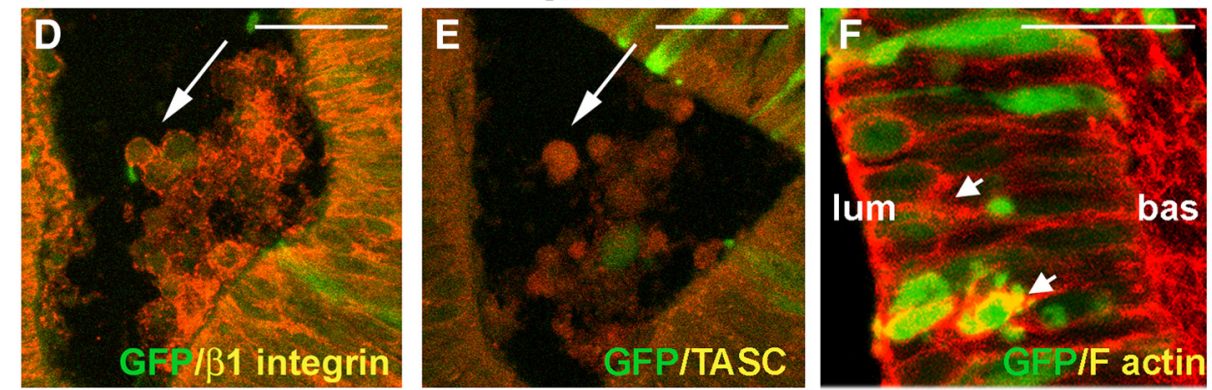

JsE3 14h
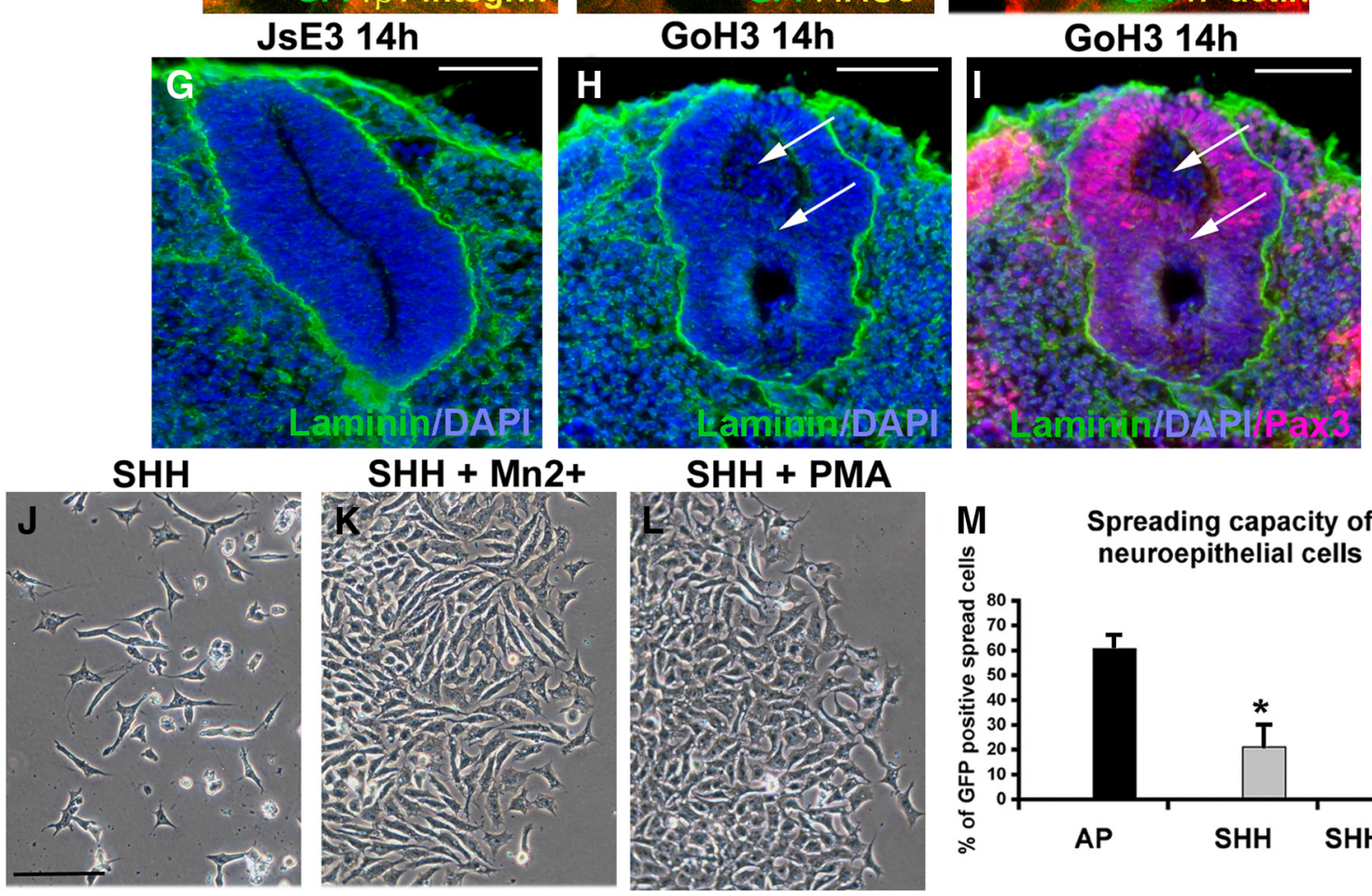

SHH + Mn2+

SHH + PMA
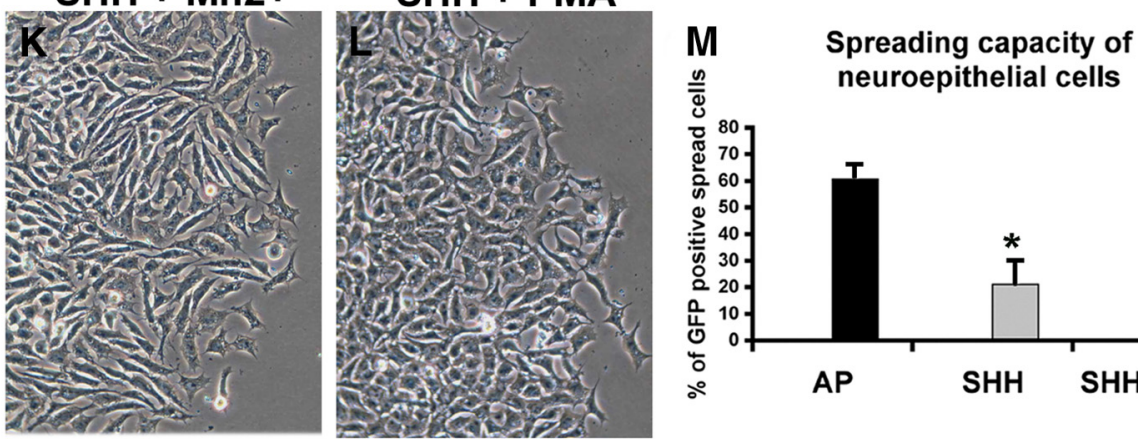

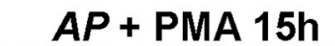

Shh + PMA 15h
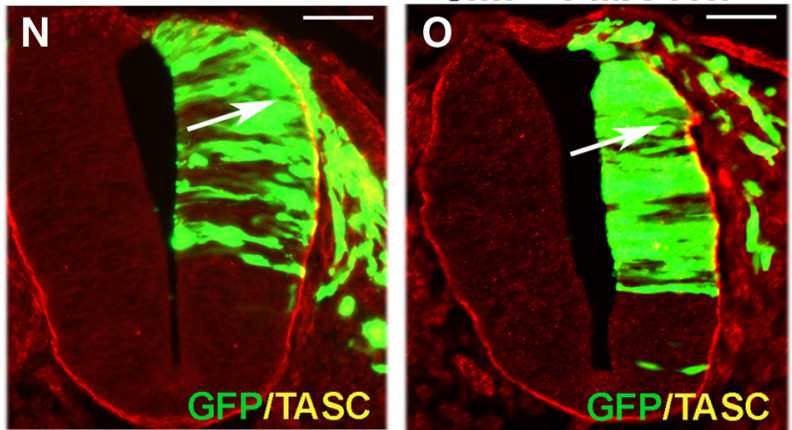
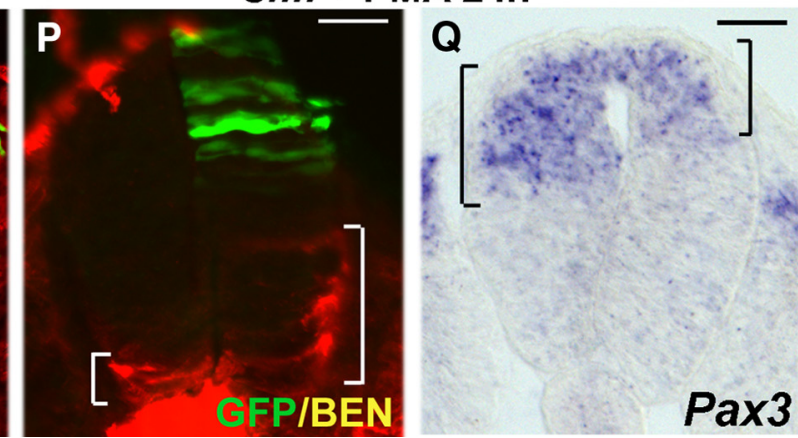

Figure 5. Shh misexpression in the neural tube provokes NE cell extrusion by anoikis as a result of $\beta 1$ integrin inactivation. $A$, Laminin distribution at 15 hpe in Shh-electroporated neural tubes shows intact basement membrane along NE cells. $\boldsymbol{B}-\boldsymbol{E}$, Distribution of total $(\boldsymbol{B}, \boldsymbol{D})$ and conformationally active $(\boldsymbol{C}, \boldsymbol{E}) \beta 1$ integrins in Shh-electroporated neural tubes at 15 hpe $(\boldsymbol{A}-\boldsymbol{E})(\boldsymbol{n}=10)$. Shh misexpression does not alter the overall expression pattern of integrins even in cells extruded into the lumen ( $\boldsymbol{D}$, arrow) but severely reduces the pool of active integrins (Figure legend continues.) 
(Duband et al., 2009). Caudal neural tube explants flattened on the substratum and formed an epithelial monolayer in vitro (Fig. $1 \mathrm{M})$, revealing the propensity of NE cells at this stage to develop matrix adhesions over cell-cell interactions. NE cell adhesion properties evolved progressively more rostrally as only dorsal cells flattened and migrated, ventral cells remaining as a cohesive structure barely adhering to FN (Fig. $1 N$ ). Finally, at the somite level, NE cell adhesive properties shifted completely from a preferential matrix adhesion to a prominent cell-cell adhesion; neural tube explants retained their hollow tube shape and were surrounded by a large outgrowth of NC cells (Fig. 1O).

\section{Ectopic expression of Shh induces morphological defects independently of its differentiative and proliferative effects} We then analyzed the effect of Shh misexpression in the dorsal one-half of the neural tube at the level of the caudal mesoderm in 15-20 somite stage chick embryos. Neural tubes were first examined at 48 hpe, corresponding to $40-45$ somite stage embryos. In contrast to control embryos electroporated with a construct encoding alkaline phosphatase $(A P)$, which showed no overt malformations (Fig. 2C,D), the electroporated side of the Shhmisexpressing neural tube appeared as a compact, poorly stratified epithelium shorter and thinner than the contralateral side (Fig. $2 A, B$ ). In addition, the number of GFP-positive cells was lower in the Shh-expressing neural tube, and, although motor neurons extended axons at the periphery, the spinal ganglia were much reduced in size (Fig. $2 A, B$ ). To determine whether these morphological defects resulted from Shh affecting differentiation, proliferation, or adhesion, we examined the neural tube morphology at different times after electroporation. Ectopic expression of Shh was observed at 4 hpe, as assessed by detection of mouse Shh mRNA (data not shown), and from 6 hpe on (20-25 somite stage), GFP-positive and -negative cells were seen extruding into the lumen of the neural tube, although its overall epithelial aspect was apparently not affected (Fig. $2 E, F$ ). The cell bodies of GFP-expressing cells were often located toward the luminal side of the neural tube. Cell extrusion was never observed in the lumen of the neural tube in AP-electroporated embryos (Fig. $2 G, H)$. TUNEL and detection of PH3 immunoreactivity showed no aberrant apoptosis and proliferation in the neural tube (Fig. $2 \mathrm{~L}-\mathrm{O}$ ), indicating that cell extrusion was not attributable to changes in cell death or mitosis. At 15 hpe (28-30 somite stage), the number of cells accumulating in the lumen increased (Fig.

\section{$\leftarrow$}

(Figure legend continued.) on the basal surface of NE cells (compare arrows in $\boldsymbol{B}$ and $\boldsymbol{C}$ ) and in extruded cells (compare arrows in $\boldsymbol{D}$ and $\boldsymbol{E}$ ). $\boldsymbol{F}$, F-actin distribution at 15 hpe in Shhelectroporated neural tubes. The short arrows point at round cells with disorganized actin. lum, Luminal side; bas, basal side. $\mathbf{G}-\mathbf{I}$, Inhibition of integrin function in mouse embryo explants mimics Sh h misexpression in the chick. $\boldsymbol{H}, \boldsymbol{I}$, E9.5 mouse embryos explants cultured for $14 \mathrm{~h}$ with $\mathrm{GoH} 3 \mathrm{mAb}$ to $\alpha 6$ integrin subunit and stained for laminin and Pax3. The arrows point at cells accumulated in the lumen. $\mathbf{G}$, Control embryos treated with the JsE3 rat mAb against an irrelevant $50 \mathrm{kDa}$ cell surface antigen. J-Q, The inhibitory effect of $\mathrm{Shh}$ misexpression on cell adhesion and migration is reversed by agents known to activate integrins. $J-L$, Morphology of NC cells cultured for $24 \mathrm{~h}$ on $2 \mu \mathrm{g} / \mathrm{ml} \mathrm{FN}$ and $10 \mu \mathrm{g} / \mathrm{ml} \mathrm{SHH}$ adsorbed onto the substratum in control medium $(\boldsymbol{J})$ or in the presence of $1 \mathrm{~mm} \mathrm{Mn}^{2+}(\boldsymbol{K})$ or of $1 \mu \mathrm{g} / \mathrm{ml} \mathrm{PMA} \mathrm{(L).} \mathrm{Scale} \mathrm{bars,} 50$ $\mu \mathrm{m} . M$, Spreading capacity (mean $\pm S D ;{ }^{*} p<0.05$ ) of GFP-positive NE cells on $20 \mu \mathrm{g} / \mathrm{ml} \mathrm{FN}$ (AP, SHH) and with $1 \mu \mathrm{g} / \mathrm{ml}$ PMA (SHH+PMA) $(n=10) . \mathbf{N}-\mathbf{Q}$, PMA treatment prevents morphological defects provoked by $\operatorname{Sh} h$ misexpression. Distribution at $15 \mathrm{hpe}(\boldsymbol{N}, \mathbf{O})$ and $24 \mathrm{hpe}$ $(\boldsymbol{P}, \mathbf{Q})$ of active $\beta 1$ integrins $(\boldsymbol{N}, \mathbf{0}), \mathrm{BEN}(\boldsymbol{P})$, and $\operatorname{Pax} 3(\mathbf{Q})$ in neural tubes electroporated with $A P$ (N) $(n=6$ of 8$)$ or $\operatorname{Shh}(\mathbf{O}-\mathbf{Q})(n=10$ of 13$)$ and treated with PMA. The arrows point at TASC staining apposed to the basal lamina of electroporated cells. The brackets in $\boldsymbol{P}$ and $\mathbf{Q}$ show the expansion or reduction of the expression domains of $\mathrm{BEN}$ and $\mathrm{Pax} 3$ along the dorsoventral axis after Shh misexpression. Scale bars, $50 \mu \mathrm{m}$.
$2 P)$, correlating with a dramatic narrowing of the neural tube (Fig. $2 I, J$ ). In addition, no significant modification was observed in proliferation (Fig. 2O,Q), and apoptosis was detected only in cells inside the lumen (Fig. $2 N, P$ ), meaning that death occurred as a result of extrusion. From 24 hpe, ectopic expression of Shh induced a significant increase in proliferation (Fig. 2Q), as described previously (Cayuso et al., 2006). SHH effect also affected the NC population. From 15 hpe, only a few NC cells delaminated, but none migrated (Fig. $2 K$ ), thereby explaining the almost complete absence of spinal ganglia (Fig. $2 \mathrm{~B}$ ).

We then investigated whether Shh affected the morphology of the neural tube by altering NE cell patterning. At 6 hpe, when cell extrusion was already observed (Fig. $3 A$ ), neither expression of $P a x 3$, a dorsal neural tube marker, was altered, nor expression of BEN and Islet1, two motor neuron markers, was induced (Fig. $3 A-C$ ) (data not shown), showing that a change in neural tube patterning did not account for early Shh morphological effect. Neural progenitor identity was only perturbed at 24 hpe (35 somite stage embryo), with a great reduction of $\mathrm{Pax} 3$ expression in the Shh-expressing side of the neural tube and a few ectopic motoneurons appearing more dorsally (Fig. $3 E-G$ ). An important ventralization of the neural tube was obvious at $48 \mathrm{hpe}$, with a dorsal shift of the lateral motor column (Fig. 3I,J). Therefore, the early morphological changes provoked by ectopic Shh in the neural tube can be attributed neither to changes in NE cell identity nor to defects in cell proliferation, but to other alterations leading to cell extrusion into the lumen. Moreover, consistent with previous reports (Marigo and Tabin, 1996; Williams et al., 1999; Charrier et al., 2001), feedback upregulation of Ptc1, occurring in response to Shh signaling, was only noted from 24 hpe and was massive at 48 hpe (Fig. $3 D, H, K$ ), underlying the possibility that activation of the classical Shh pathway was turned on after NE cell extrusion began and only occurred coincident with the first signs of ventralization and the effect $\mathrm{SHH}$ has on proliferation (Fig. 2O). This observation is consistent with our previous in vitro results showing that $\mathrm{SHH}$ effect on cell-matrix adhesion occurred by a mechanism independent of the classical Ptc-Gli signaling pathway (Testaz et al., 2001; Jarov et al., 2003).

Given that SHH signaling is induced gradually after a caudorostral wave that accompanies changes in cell adhesion, we tested whether NE cells responded evenly to Shh misexpression throughout the neuraxis. Electroporations were performed either in the caudal neural tube or at the level of the last-formed somites in 15-25 somite stage embryos. When expressed caudally, Shh caused massive cell extrusion at all developmental stages (Fig. $3 L$ ). In contrast, when expressed more rostrally, Shh misexpression only marginally affected the morphology of the neural tube with no cell extrusion (Fig. $3 M$ ), although it still altered its dorsoventral patterning (Fig. $3 \mathrm{~N}, \mathrm{O}$ ). These results therefore show that, whereas caudal and rostral neural tubes respond equally well to the patterning signals of $\mathrm{SHH}$, only immature NE cells in the caudal neural tube, which are actively remodeling their adhesion properties, are responsive to the morphological effect of $\mathrm{SHH}$.

\section{Ectopic expression of $S h h$ induces neural tube deformities by causing cell anoikis}

NE cell extrusion in the lumen of the neural tube followed by cell death is reminiscent of anoikis, an apoptotic process affecting epithelial cells as a consequence of loss of integrin-mediated adhesion (Frisch and Screaton, 2001). To determine whether Shh misexpression induced cell anoikis, we first studied its effect on NE cell-matrix adhesion. Neural tubes electroporated with Shh 


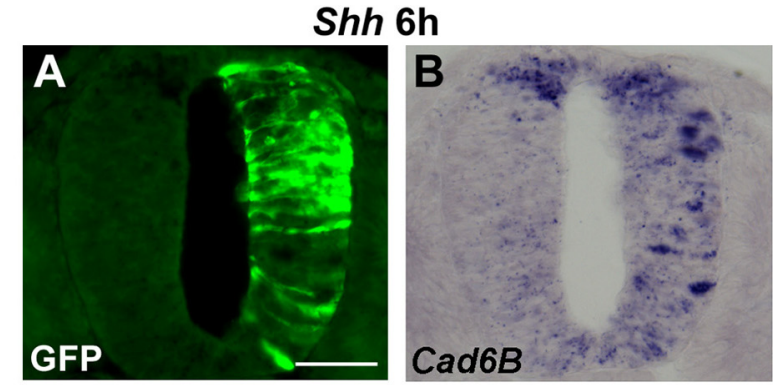

Shh $15 \mathrm{~h}$
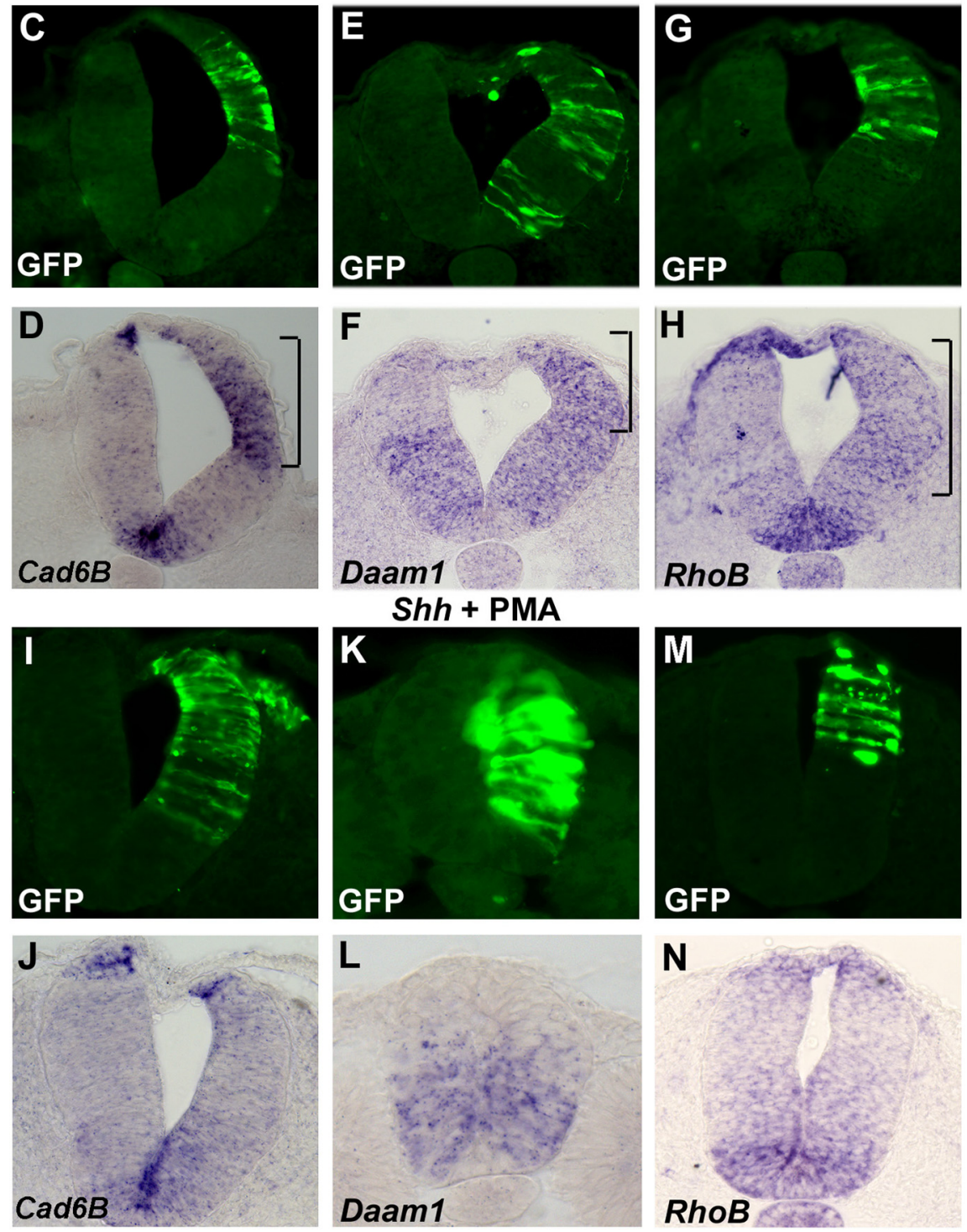

Figure 6. Shh misexpression in the neural tube alters expression of cell adhesion and polarity genes. $\boldsymbol{A}-\boldsymbol{H}$, Expression patterns at 6 hpe $(\boldsymbol{A}, \boldsymbol{B})(n=8)$ and $15 \mathrm{hpe}(\boldsymbol{C}-\boldsymbol{H})(n=10)$ of $\operatorname{Cad} 6 \boldsymbol{B}(\boldsymbol{B}, \boldsymbol{D}), \operatorname{Daam} 1(\boldsymbol{F})$, and $R h \circ B(\boldsymbol{H})$ in neural tubes of Shh-electroporated embryos, revealing induction of these genes by $S h h$. The brackets indicate ectopic expression in $\boldsymbol{D}, \boldsymbol{F}$, and $\boldsymbol{H}$. $\boldsymbol{I}-\boldsymbol{N}$, Expression patterns at 15 hpe of $\operatorname{Cad} 6 B(\boldsymbol{J}), \operatorname{Daam} 1(\boldsymbol{L})$, and $R h o B(\boldsymbol{N})$ in neural tubes of embryos electroporated with Shh and treated with PMA $(n=8$ of 11). Scale bar, $50 \mu \mathrm{m}$.

were explanted onto FN to assess the migratory and adhesive properties of NC and NE cells. Although in control explants, NC cells exhibited their normal migratory pattern with a large outgrowth of cells surrounding the neural tube (Fig. 4A-C), Shhexpressing neural tubes adhered poorly to FN and few GFPpositive NC cells delaminated. Ultimately, the explants exhibited an unusual undulated and compact morphology, with clumps of cells in the lumen of the neural tube (Fig. $4 D-G)$. Measurement of the adhesive capacities of isolated $\mathrm{NE}$ cells revealed a threefold reduction of spreading in Shhexpressing cells (Fig. $4 H$ ). These results therefore demonstrate that Shh misexpression leads to rapid and massive inhibition of cell-matrix adhesion and are supportive of an anoikis mechanism leading to NE cell extrusion and neural tube shrinkage.

We then searched for Shh targets responsible for the reduction of matrix adhesion. We found no alterations in the distribution of laminin and FN in the neural tube basement membrane after Shh misexpression (Fig. 5A) (data not shown), indicating that Shh did not induce cell extrusion through matrix degradation. Likewise, $\beta 1$ integrin immunoreactivity was normal, being accumulated on the basal side of the Shh-electroporated neural tube (Fig. 5B, arrows). However, immunoreactivity with TASC, an antibody specific for conformationally active integrins (Cruz et al., 1997), was dramatically reduced basally on NE cells of the Shhexpressing area (Fig. 5C, arrows). Moreover, cells in the lumen of the neural tube did not exhibit TASC staining, although they still had $\beta 1$ integrin accumulation on their surface (Fig. 5D,E). In addition, cells that accumulated toward the luminal side before extrusion exhibited a round morphology with disorganized actin cytoskeleton (Fig. 5F).

If integrins are indeed inactivated by $\mathrm{SHH}$, then blocking their function should affect neural tube organization in a similar way as Shh misexpression. The $\alpha 6 \beta 1$ integrin being of the major laminin-binding integrins expressed by NE cells (BronnerFraser et al., 1992; Bajanca et al., 2004), trunk explants of mouse E9.5 embryos were cultured with an antibody that specifically inhibits the binding of the $\alpha 6 \beta 1$ integrin to laminin (Sonnenberg et al., 1988). Although explants cultured with a control antibody showed no alteration of neural tube morphology (Fig. 5G), culture of explants with the blocking antibody caused a dramatic luminal extrusion of NE cells (Fig. $5 H$ ), thereby mimicking the phenotype of Shh-misexpressing neural tubes. Interestingly, this effect was also restricted to the caudal neural tube (data not shown) and occurred independently of changes in the dorsoventral polarity of the neural tube (Fig. 5I).

Finally, we sought to reverse the effect of misexpressing Shh by artificially activating integrins, using either $\mathrm{Mn}^{2+}$, which locks integrins in a conformationally active form, or phorbol 12myristate 13-acetate (PMA) known to stimulate integrin insideout and outside-in signaling (Han et al., 2006; Lee et al., 2006). 


\section{Hip1 15h}
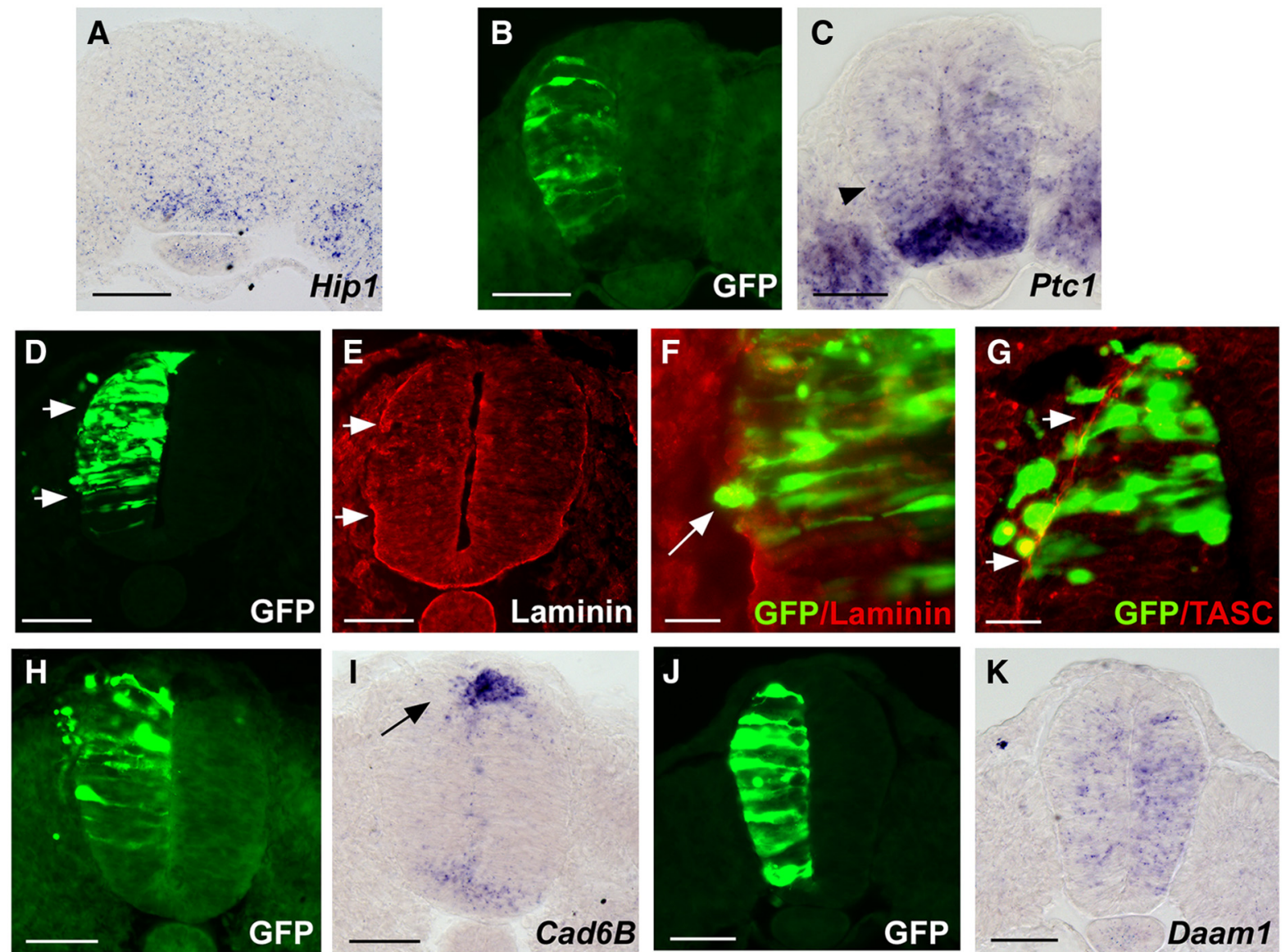

Hip1 24h
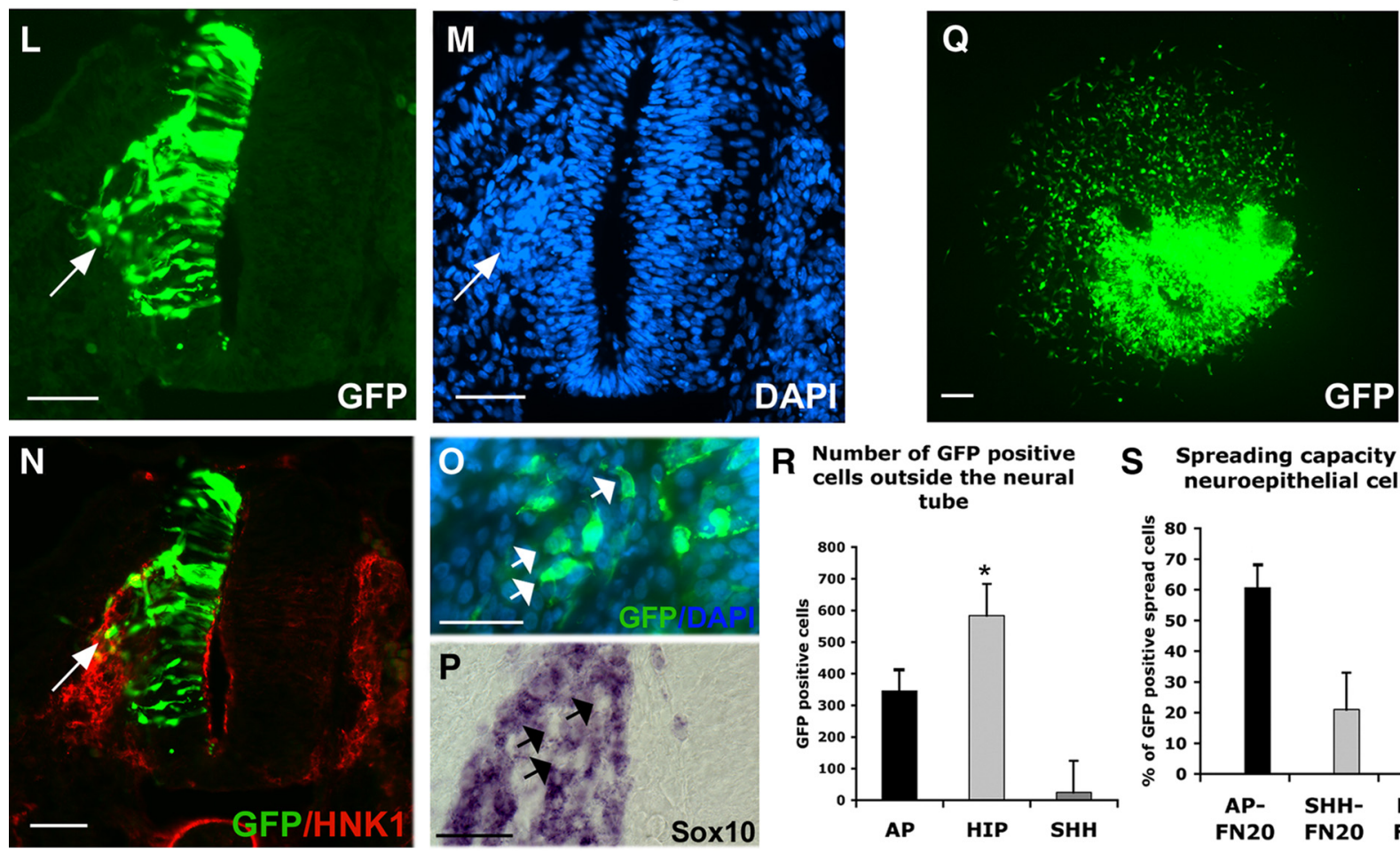

S Spreading capacity of

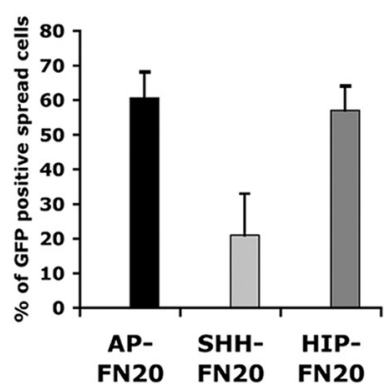

Figure 7. Antagonizing Shh activity by Hip 1 misexpression induces ectopic NE cell delamination. $A$, Normal expression pattern of $H$ ip 1 in 20 somite stage embryos at the level of the unsegmented mesoderm. $\boldsymbol{B}-\boldsymbol{K}$, Morphology and molecular characterization of neural tubes at 15 hpe in Hip 1-electroporated embryos $(n=8) . \boldsymbol{B}, \boldsymbol{C}$, Ptc1 expression reveals a reduction of Shh signal. $\boldsymbol{D}-\mathbf{G}$, Hip 1 expression induces ectopic NE cell delamination ( $\boldsymbol{F}$, arrow) associated with breakdown of the basal lamina ( $\boldsymbol{D}, \boldsymbol{E}$, short arrows), but no inactivation of $\beta 1$ integrins $(\boldsymbol{G}$, short arrows). $\boldsymbol{H}-\boldsymbol{K}$, Repression of Cad6B and Daam 1 expression by Hip 1 misexpression. The arrow in I points at the absence of Cad6B at the apex of the neural tube in the electroporated side. (Figure legend continues.) 
Neural tube explants cultured on FN with $\mathrm{SHH}$ produced only a few poorly spread NC cells at their periphery, but addition of either $\mathrm{Mn}^{2+}$ or PMA totally restored spreading and migration (Fig. 5J-L). Likewise, NE cells expressing Shh exhibited normal levels of spreading with PMA (Fig. 5M). Because $\mathrm{Mn}^{2+}$ had toxic effects on embryos after prolonged exposure, we only tested the effect of PMA on the neural tube morphology after Shh misexpression. Neural tubes electroporated with Shh and treated with PMA appeared normal at 15 hpe, with no cells extruding into the lumen and numerous migrating NC cells. In addition, they showed strong $\beta 1$ integrin expression (data not shown) and TASC staining on the basal side of NE cells, just as observed in control embryos (Fig. $5 \mathrm{~N}, \mathrm{O}$ ). Moreover, Shh still altered dorsoventral patterning (Fig. $5 P, Q$ ), demonstrating that activation of integrins by PMA specifically reversed the inhibitory effect of Shh on matrix adhesion without affecting its dorsoventral patterning effect. Together, these results demonstrate that the earliest effect of Shh misexpression in the neural tube is to induce NE cell detachment and subsequent anoikis by inactivating integrins. It is noteworthy that, in 15-20 somite stage neuraxis, conformationally active $\beta 1$ integrins revealed by TASC staining appeared highly and uniformly distributed over the entire surface of NE cells at caudal levels and were progressively restricted to the basal pole at more rostral levels (Duband et al., 2009). This expression pattern is completely consistent with the graded restriction of NE cell-matrix adhesion along the rostrocaudal axis under the control of Shh activity.

\section{Shh misexpression induces changes in cell-cell adhesion and cell polarity}

Because Shh misexpression caused massive cell compaction in the neural tube in addition to cell extrusion, we analyzed whether it affected cell-cell adhesion and cell polarity. Cell-cell adhesion in the early neural tube is primarily mediated by $\mathrm{N}$-cadherin and cadherin-6B (Nakagawa and Takeichi, 1995), and cell polarity relies in part on Daam1, a member of the formin family expressed in the ventral neural tube (Kida et al., 2004). We did not detect significant changes in $\mathrm{N}$-cadherin protein expression (data not shown), but robust induction of Cad6B expression was observed, starting as early as 6 hpe in cells overexpressing Shh (Fig. 6A-D). Likewise, Daam 1 expression was induced at 6 hpe first faintly (data not shown), and then more markedly at 15 hpe (Fig. 6E,F). Because NC delamination was severely reduced in Shh-overexpressing neural tubes, we analyzed the expression pattern of $R h o B$, a Rho family GTPase proposed to be required for NC delamination (Liu and Jessell, 1998). To our surprise, we observed induction of $R h o B$ in Shh-expressing cells at 15 hpe (Fig. 6G,H).

Because of cross talks between cell-matrix and cell-cell adhesion systems (Monier-Gavelle and Duband, 1997), we analyzed whether increase in cell cohesion caused by Shh misexpression could be attributable to inhibition of matrix adhesion. Shhelectroporated neural tubes were treated with PMA to restore

\footnotetext{
$\leftarrow$

(Figure legend continued.) $\mathbf{L}-\boldsymbol{P}$, Characterization of delaminating cells at 24 hpe in Hipelectroporated embryos $(n=7)$, showing that delaminated cells ( $\boldsymbol{L}, \boldsymbol{M}$, arrows) express no NC markers ( $\boldsymbol{N}, \boldsymbol{P}$, arrows). $\mathbf{Q}$, Hip1-electroporated NE cells are highly migratory in culture. Hip1electroporated neural tubes cultured for $18 \mathrm{~h}$ on FN, showing spreading and migration of GPFpositive NE cells and reduced neural tube compaction (compare with Fig. 4B). $R$, Number ( \pm SD) $\left({ }^{*} p<0.05\right)$ of GFP-positive cells situated outside the electroporated neural tube at $24 \mathrm{hpe}(n=$ 6). Quantitation was done on a total of 50 serial sections for each embryo $(n=6)$. S, Spreading capacity (mean \pm SD) of GFP-positive NE cells on a FN-coated ( $20 \mu \mathrm{g} / \mathrm{ml}$ ) substrate (AP-FN20, SHH-FN20, HIP-FN20; $n=6$ ). Scale bars: $\boldsymbol{A}-\boldsymbol{E}, \boldsymbol{H}-\mathbf{Q}, 50 \mu \mathrm{m} ; \boldsymbol{F}, \mathbf{G}, 10 \mu \mathrm{m}$.
}

matrix adhesion and examined for cadherin expression. Shhinduced upregulation of $\mathrm{Cad} 6 \mathrm{~B}$ was abolished on PMA treatment (Fig. 6I,J), suggesting that cell cohesion occurred merely as a secondary event because of decreased matrix adhesion. Interestingly, PMA also reversed Shh effect on Daam 1 and RhoB expressions (Fig. $6 \mathrm{~K}-\mathrm{N}$ ). Our results then show that, in the neural tube, Shh coordinates integrin-dependent matrix adhesion, which in turn affects cadherin-mediated cell-cell adhesion and the organization of actin cytoskeleton.

\section{Blocking Shh activity provokes ectopic NE cell delamination}

To further elucidate the role of SHH signaling in the regulation of cell adhesion and polarity, we sought to block its function either by ectopically expressing the Hedgehog-interacting protein HIP1 or by injecting blocking antibodies against $\mathrm{SHH}$ protein into the lumen of the neural tube. Hip1 encodes a $\mathrm{SHH}$-sequestering membrane protein expressed in response to SHH signals (Chuang and McMahon, 1999). In the caudal region of 15-25 somite stage embryos, Hip1 is expressed in the ventral part of the neural tube, where Shh activity is high (Fig. 7A). Misexpression of a secreted form of HIP1 in the dorsal one-half of the neural tube induced downregulation of Ptc1, attesting reduction of Shh activity (Fig. 7 B, C). Hip1 misexpression caused dramatic alterations in NE cell organization. Basal lamina disruption was observed at 15 hpe, associated with ectopic cell delamination (Fig. 7D-F). However, cells retained strong TASC staining on their basal side (Fig. 7G). This resulted at 24 hpe in a severe disorganization of the neural tube (Fig. $7 L, M$ ) and in the presence of numerous GFP-positive cells outside the neuroepithelium (Fig. 7R). Hip1 misexpression induced repression of Cad6B and Daaml (Fig. $7 \mathrm{H}-\mathrm{K}$ ), but no obvious change in RhoB (data not shown). Hip1-expressing neural tube explants flattened on the substratum, with numerous GFP-positive cells migrating at the periphery (Fig. 7Q). In addition, Hipl-expressing cells exhibited a strong capacity to adhere to the substratum (Fig. $7 S$ ). Nevertheless, although delaminated cells migrated with the NC cell stream for $\sim 36 \mathrm{~h}$, they did not acquire a NC phenotype, as evidenced by their being negative for NC markers, such as HNK1 (Fig. 7N), Sox10 (Fig. 7O,P), FoxD3, and Snail2 (data not shown).

Two blocking antibodies against $\mathrm{SHH}$ protein, mAbs $5 \mathrm{E} 1$ and APG6, were also used to antagonize SHH activity (Wang et al., 2000). Injection of 5E1 (Fig. 8A) and APG6 (data not shown) in the lumen of the neural tube induced downregulation of Ptc1 expression (compare with Fig. $1 G$ ), attesting to the reduction of SHH signaling. As observed for Hip1 misexpression, basal lamina disruption was observed $18 \mathrm{~h}$ after injection of antibodies and correlated with ectopic cell delamination (Fig. $8 C, D, F, G$ ). In contrast, nonblocking ACD1 antibodies to $\mathrm{SHH}$ showed no effect on the neural tube (data not shown). To quantify cell delamination, neural tubes were simultaneously electroporated with GFP and injected with SHH-blocking antibodies, revealing an increase in GFP-positive cells outside the neural tube (Fig. $8 \mathrm{~B}$ ). Similarly to when Hip1 was misexpressed, delaminated cells did not acquire a NC phenotype as evidenced by the absence of HNK1 staining in the delaminated, GFP-positive cells (Fig. 8E,H).

Interestingly, caudal neural tube treatment with PMA alone elicited the same phenotype as Hip1 misexpression. NE cells cultured in the presence of PMA lost their epithelial morphology and acquired a motile phenotype with numerous focal contacts and redistribution of F-actin in lamellipodia (Fig. 9A-D). Consistent with this, in vivo injection of PMA into the neural tube significantly increased the number of migrating NC cells (Fig. $9 E, F)$. In addition, PMA caused a severe reduction in Cad6B, 
Daam1, and RhoB expression in NE cells, particularly in the dorsal neural tube, both in vivo and in explants (Fig. $9 G-R$ ). This suggests that increasing matrix adhesion using Hip1 overexpression, SHH blocking antibodies, or PMA treatment is sufficient to decrease cell-cell adhesion and induce cell delamination.

BMP4 misexpression in the neural tube does not cause NE cell delamination Because we postulated that $\mathrm{SHH}$ and BMP4 could exert opposite effects on the adhesive properties of NE cell during neural tube development, we analyzed whether Bmp4 misexpression in the neural tube could trigger ectopic cell delamination. Bmp4 did not perturb Shh activity as shown by Ptc1 expression (Fig. 10 A,B), indicating that it does not directly antagonize Shh signal. However, Bmp4 induced precocious NC emigration, as shown by the greater number of $\mathrm{HNK} 1$ cells exiting the caudal neural tube compared with the contralateral side (Fig. 10C). Interestingly, ectopic Bmp4 caused an important disruption of the neural tube basal lamina but no ectopic delamination (Fig. 10D-F). Intense cell dispersion was only observed dorsally in the prospective NC cell area (Fig. 10G,H), resulting in the doubling of GFP-positive cells peripherally $(748 \pm 80$ for BMP $4, n=$ 7 , vs $346 \pm 62$ for AP, $n=4)$. In addition, all GFP-positive cells exiting the neural tube expressed NC markers, such as HNK1 (Fig. 10I), FoxD3, Sox10, and Snail2 (data not shown). These results therefore indicate that BMP4 does not antagonize SHH effect on cell-matrix and cell-cell adhesion and that its dispersion-promoting effect is restricted to prospective NC cells.

\section{Discussion}

During neural tube morphogenesis, $\mathrm{HH}$ signaling pathway simultaneously controls progenitor specification and proliferation (Ulloa and Briscoe, 2007). Here, we show that Shh is also able to coordinate cell adhesion and polarity during neural tube formation by controlling integrin-matrix adhesion, cell-cell cadherin contacts, and cell polarity genes.

Ectopic expression of Shh in the caudal neural tube blocks $\beta 1$ integrin activation, a mechanism essential for cell-matrix adhesion. This observation is consistent with our in vitro data showing that $\mathrm{SHH}$ induces a conformational shift of integrins toward an inactive state in NC cells (Testaz et al., 2001). In vivo, this results in inhibition of NE cell anchorage to the basal lamina and cell extrusion at the apical side, ultimately producing anoikis in the lumen of the neural tube. This rapid effect precedes those on cell specification and proliferation and provokes shrinkage of the neural tube and reduction of NC derivatives. Moreover, blocking $\alpha 6 \beta 1$ integrin in mouse embryo explants phenocopies the NE cell extrusion seen after $S h h$ misexpression in the neural tube, raising the possibility that SHH could specifically inactivate $\alpha 6 \beta 1$ integrin in NE cells. Concomitant with inhibition of matrix adhesion, cell cohesion increases by upregulation of $\mathrm{Cad} 6 \mathrm{~B}$ expression. This is fully consistent with reports showing that $\mathrm{NC}$ emigration requires $\mathrm{Cad} 6 \mathrm{~B}$ repression by Snail2 (Taneyhill et al., 2007). Knocking down Cad6B leads to premature $\mathrm{NC}$ migration and $\mathrm{Cad} 6 \mathrm{~B}$ overexpression in the neural tube induces massive cell spilling into the lumen (Coles et al., 2007), a phenotype similar to the one reported here. We did not detect significant changes in $\mathrm{N}$-cadherin protein expression, but it is conceivable that cell cohesion may result from an increase in $\mathrm{N}$-cadherin stability in adherens junctions rather than an increased expression. Shh overexpression also induces the expression of two effectors implicated in actin cytoskeletal reorganization, Daam1, a formin-homology protein, and $R h o B$, a member of the Rho family GTPases. Increase of RhoB expression was unexpected because it was reported to be necessary for NC delamination (Liu and Jessell, 1998). However, it has recently been shown that Rho GTPases are widely expressed throughout the neural tube and that Rho overstimulation causes rounding of NE cells and apical extrusion into the lumen (Kinoshita et al., 2008). These observations suggest that Rho GTPases are involved in cytoskeleton stabilization during epithelial morphogenesis (Van Aelst and Symons, 2002). Moreover, Rho GTPases cooperate with Daam1 in the regulation of planar cell polarity (Zallen, 2007) and Daaml and RhoB have also been implicated in the endocytosis of adhesion receptors and growth factors (Kida et al., 2007; Witze et al., 2008). Upregulation of both genes on Shh misexpression in the dorsal neural tube suggests that reducing matrix adhesion and increasing cell cohesion by $\mathrm{SHH}$ signaling also contributes to reinforcement of cell polarity.

Addition of PMA to Shh-misexpressing neural tubes blocks cell anoikis and induction of Cad6B,Daam1, and RhoB, without 

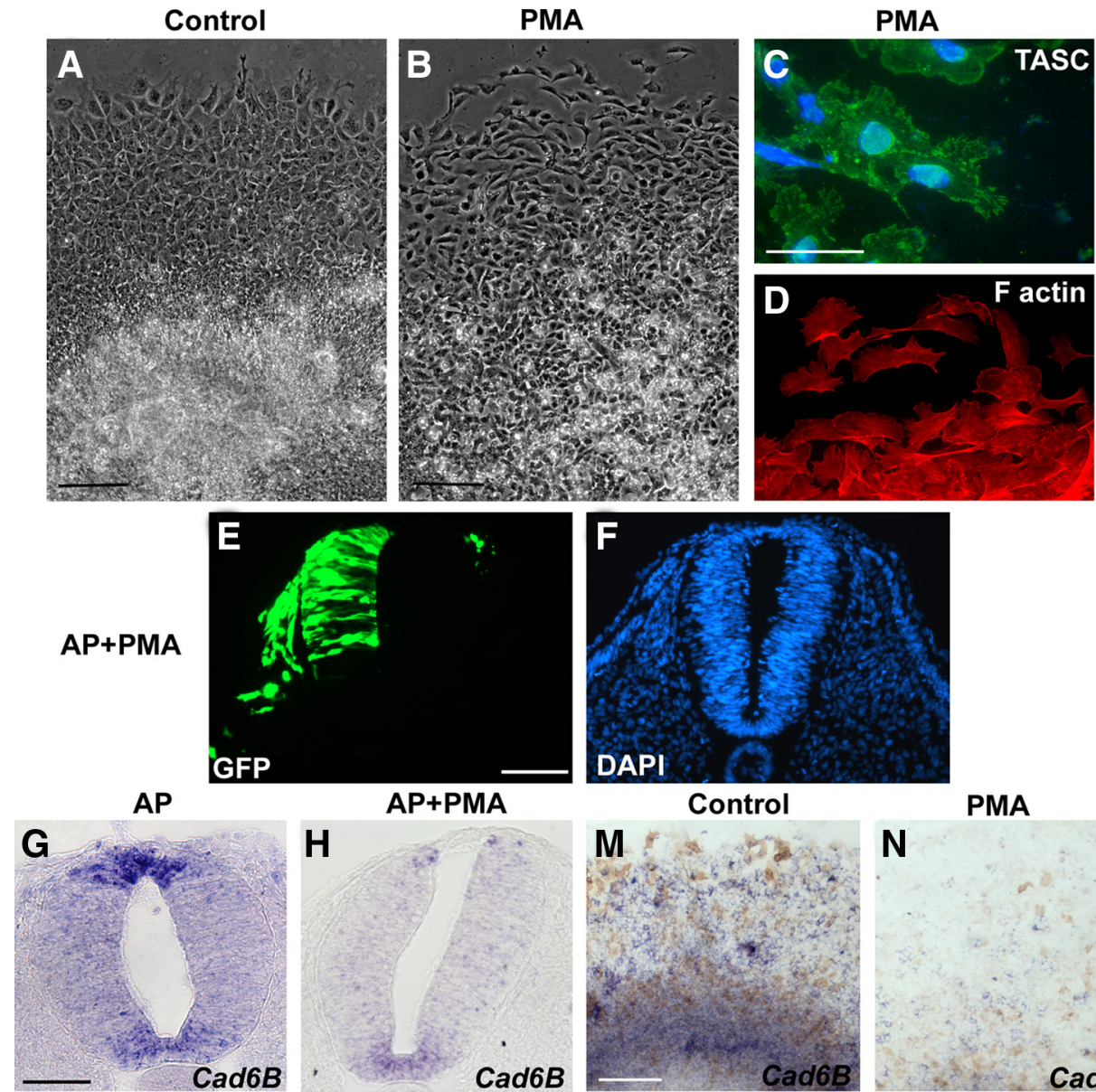

AP+PMA

Control
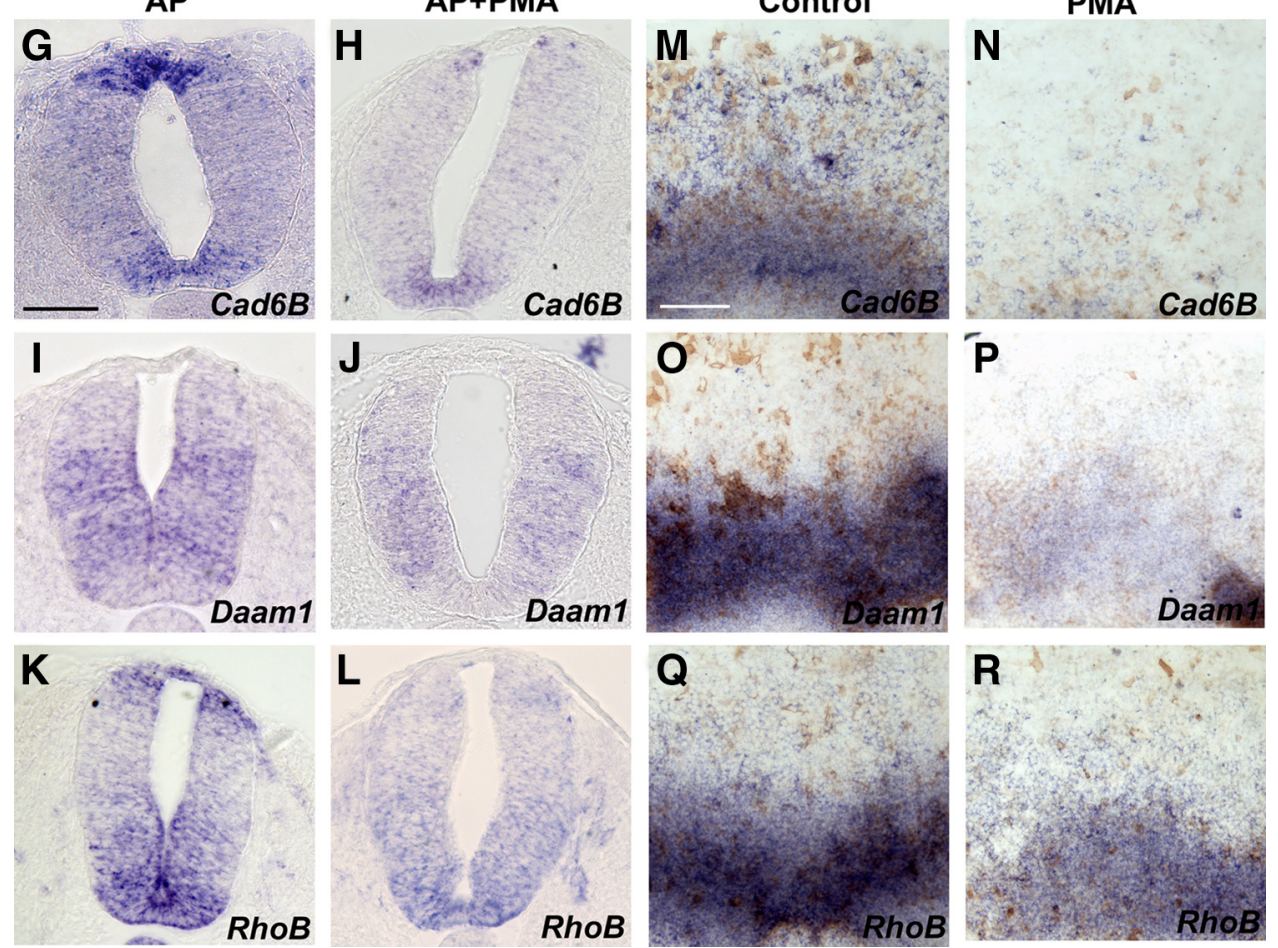

Figure 9. PMA treatment of neural tubes mimics Shh loss of function. $\boldsymbol{A}, \boldsymbol{B}$, Phase contrast views from control $(\boldsymbol{A})$ and PMA-treated $(\boldsymbol{B})$ neural tube explants at the level of the unsegmented mesoderm, after $24 \mathrm{~h}$ in culture, showing that PMA causes loss of the epithelial and compact organization of NE cells. C, D, PMA-treated NE cells stained with TASC mAb $(\boldsymbol{C})$ and phalloidin (D), revealing their mesenchymal morphology with numerous focal contacts and stress fibers. $E-G$, Injection of PMA in the neural tube of control $A P$-electroporated cells increases the number of GFP-positive cells migrating at the periphery. $\mathbf{G}-\boldsymbol{L}$, Expression patterns at 15 hpe of $\operatorname{Cad} 6 B(\boldsymbol{G}, \boldsymbol{H})$, Daam $1(\boldsymbol{I}, \boldsymbol{J})$, and $R h o B(\boldsymbol{K}, \boldsymbol{L})$ in neural tubes of $A P$-electroporated embryos treated $(\boldsymbol{H}, \boldsymbol{J}, \boldsymbol{L})$ or not $(\mathbf{G}, \boldsymbol{I}, \boldsymbol{K})$ with PMA $(n=6$ of 7$) . \boldsymbol{M}-\boldsymbol{R}$, Expression of $\operatorname{Cad} 6 B(\boldsymbol{M}, \boldsymbol{N}), \operatorname{Daam} 1(\mathbf{O}, \boldsymbol{P})$, and $R h o B(\boldsymbol{Q}, \boldsymbol{R})$ in untreated $(\boldsymbol{M}, \mathbf{O}, \mathbf{Q})$ and PMA-treated $(\boldsymbol{N}, \boldsymbol{P}, \boldsymbol{R})$ neural tube explants. Scale bars: $\boldsymbol{A}, \boldsymbol{B}, \boldsymbol{E}, \boldsymbol{F}, \boldsymbol{H}-\boldsymbol{R}$, $100 \mu \mathrm{m} ; C, D, 50 \mu \mathrm{m}$.

affecting Shh effect on the neural tube dorsoventral polarity. It is likely that the PMA effect on cell adhesion and polarity is via its capacity to enhance matrix adhesion. PMA activates PKC $\delta$, increasing phosphorylation of focal adhesion kinase and paxillin, two effectors of integrin signals (Han et al., 2006; Lee et al., 2006), but it does not activate atypical PKC involved in the organization of cadherin junctions. PMA increases the number of migrating
$\mathrm{NC}$ cells in vivo and the expression of active integrins on NE cells in vitro. In addition, PMA reverses Shh effect on adhesion and migration to levels identical with those achieved with $\mathrm{Mn}^{2+}$, which locks integrins in an active state. Moreover, integrin activation by PMA induces downregulation of Cad6B, Daam1, and RhoB expression, and Hip1 misexpression (or blocking SHH activity by antibodies) causes ectopic cell delamination and repres- 
sion of Cad6B and Daam1. Last, matrix adhesion, cell-cell adhesion, and cell polarity are known to be coordinated within tissues. Integrin signaling regulates distribution and activity of $\mathrm{N}$-cadherin during NC migration (Monier-Gavelle and Duband, 1997) and polarity regulators such as Par3 and Numb are required to maintain apical adherens junctions in NE cells (Afonso and Henrique, 2006) and control integrin endocytosis (Nishimura and Kaibuchi, 2007). Together, our observations strongly suggest that $\mathrm{SHH}$ acts first on conformation of $\beta 1$ integrins, which, in turn, induces an increase in $C a d 6 B$, Daam1, and RhoB expression, resulting in strong cell-cell adhesion and polarity. The mechanism of this coordination remains to be elucidated, but it has become clear that integrins influence gene expression, possibly via the shuttling of focal adhesion constituents between the cytoplasm and the nucleus (Hervy et al., 2006). Such a mechanism may account for $\mathrm{SHH}$ effect on cell adhesion and polarity.

The Shh-dependent coordination of cell adhesion and polarity is restricted to the caudal part of the neural tube. Ectopic expression of Shh or Hip1 (data not shown) in the neural tube at the level of somites does not affect adhesion nor cell polarity, although it shows a potent effect on cell identity. A possible explanation is that this early effect of $\mathrm{SHH}$ is progressively restricted by components known to sequester $\mathrm{SHH}$ and restrain its activity, such as Ptcl and Hipl (Chuang and McMahon, 1999; Jeong and McMahon, 2005). In the caudal neural tube, both Ptc1 and Hip1 are expressed at low levels and are gradually induced more rostrally by $S h$, thereby locally restricting its activity. This restricted caudal effect could explain why cell adhesion regulation by Shh has not been previously described, for example in Shh mouse mutants. Interestingly, Opb mouse mutants, in which Rab23 GTPase is deleted, display caudal neural tube defects strikingly reminiscent of our Shh gain-of-function experiments (Günther et al., 1994). Rab23 has been found to antagonize Shh signaling by a mechanism that does not involve $P t c 1$ and Smo receptors. Our previous in vitro data demonstrate that $\mathrm{SHH}$-induced inactivation of $\beta 1$ integrins does not require the canonical Ptc-Smo-Gli pathway (Testaz et al., 2001, Jarov et al., 2003). Consistent with this observation, in vivo, upregulation of $P t c 1$ expression in response to the activation of the classical Shh signaling pathway is only observed from 18 to 24 hpe, concomitant with the effect of Shh misexpression on neural proliferation and dorsoventral patterning. A possibility is that Shh activity affects intracellular trafficking of $\beta 1$ integrins via Rab-GTPases known to associate directly with them to favor cell migration (Caswell et al., 2007). However, blocking HH signaling pathway in zebrafish by cyclopamine induces cells to inappropriately exit the spinal cord, a phenotype reminiscent of our loss-of-function experiments (Ungos et al., 2003). Additional experiments are thus

\section{Bmp4 15h}
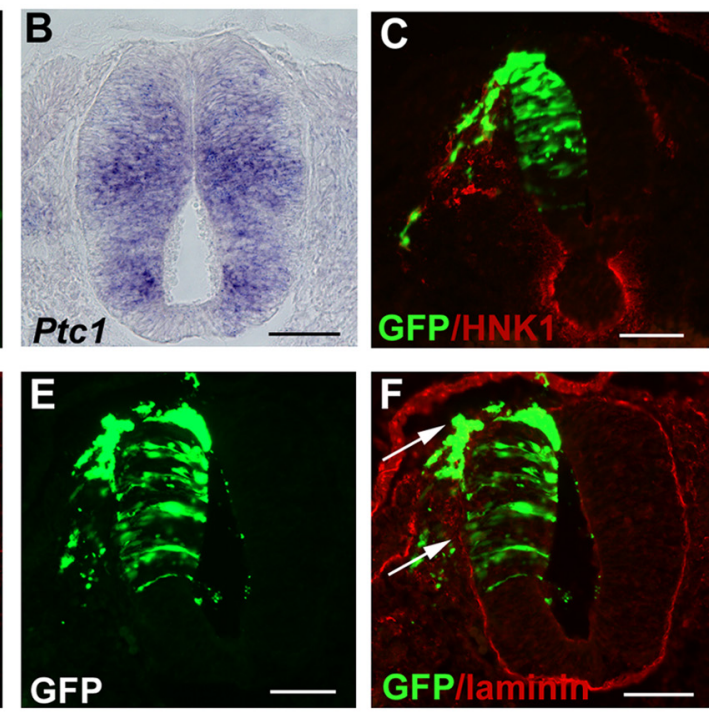

Bmp4 24h

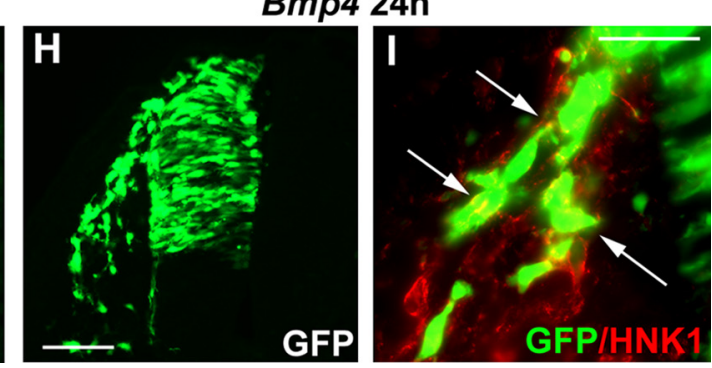

Figure 10. Ectopic expression of Bmp4 in the neural tube increases NC delamination but does not induce delamination of NE , Morphology and molecular characterization of Bmp4-electroporated neural tubes at 15 hpe $(n=10)$. $\boldsymbol{A}, \boldsymbol{B}$, Ptc (he SHH signal. $\mathbf{C}-\boldsymbol{F}$, Bmp4 expression induces breakdown of the basal lamina (arrows), but mination is only located dorsally in the prospective NC area. G-I, Bmp4 increases NC delamination at 24 hpe. Morphology of the neural tube in $A P-(\boldsymbol{G})(n=4)$ and Bmp4- $(\boldsymbol{H})(n=9)$ electroporated embryos. I, HNK1 staining showing that delaminating cells are NC cells (arrows). Scale bars, $50 \mu \mathrm{m}$.

needed to elucidate whether Shh-dependent inactivation of $\beta 1$ integrins in vivo requires the canonical Shh signaling pathway.

The local restriction of $\mathrm{SHH}$ effect on cell adhesion matches the time when the neural epithelium acquires its pseudostratified aspect (Hong and Brewster, 2006; Duband et al., 2009). Caudal NE cells are poorly cohesive, not fully polarized, and spread onto matrices using their activated $\beta 1$ integrins, which are uniformly distributed on their surface. Rostral cells are fully polarized, with apical accumulation of cadherins and basal restriction of activated integrins. SHH has been shown to concentrate at the apical region of target cells (Chamberlain et al., 2008). It is then conceivable that $\mathrm{SHH}$ would inactivate $\beta 1$ integrins at the apical side of NE cells, resulting in the accumulation of functional integrins on the basal side in contact with the extracellular matrix. Local restriction of integrin function would reduce the overall level of their signaling, relieving repression of cadherins, allowing their accumulation in cell junctions and the reorganization of apicobasal polarity (Fig. 11).

Inhibition of Shh activity in the caudal neural tube by Hip1 misexpression or injection of $\mathrm{SHH}$ antibodies induces ectopic cell delamination, showing that $\mathrm{SHH}$ is crucial for preventing migration. Delaminating cells do not acquire a NC phenotype but are able to migrate and follow NC cell streams, although they do not survive in the long term (data not shown). Similarly, ectopic expression of the Ets1 transcription factor induces NE cell 
1

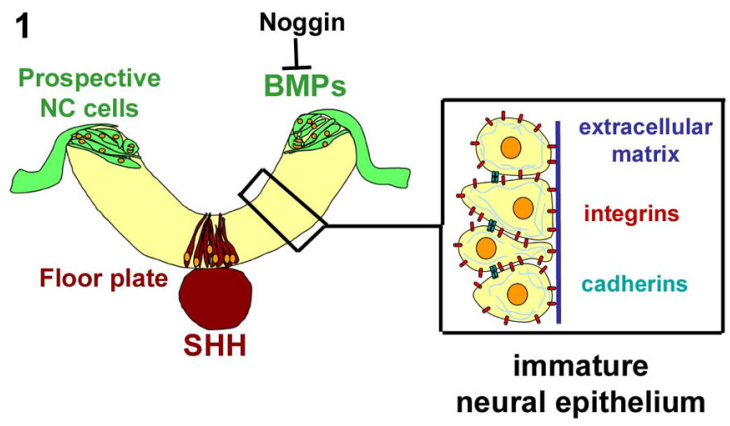

2
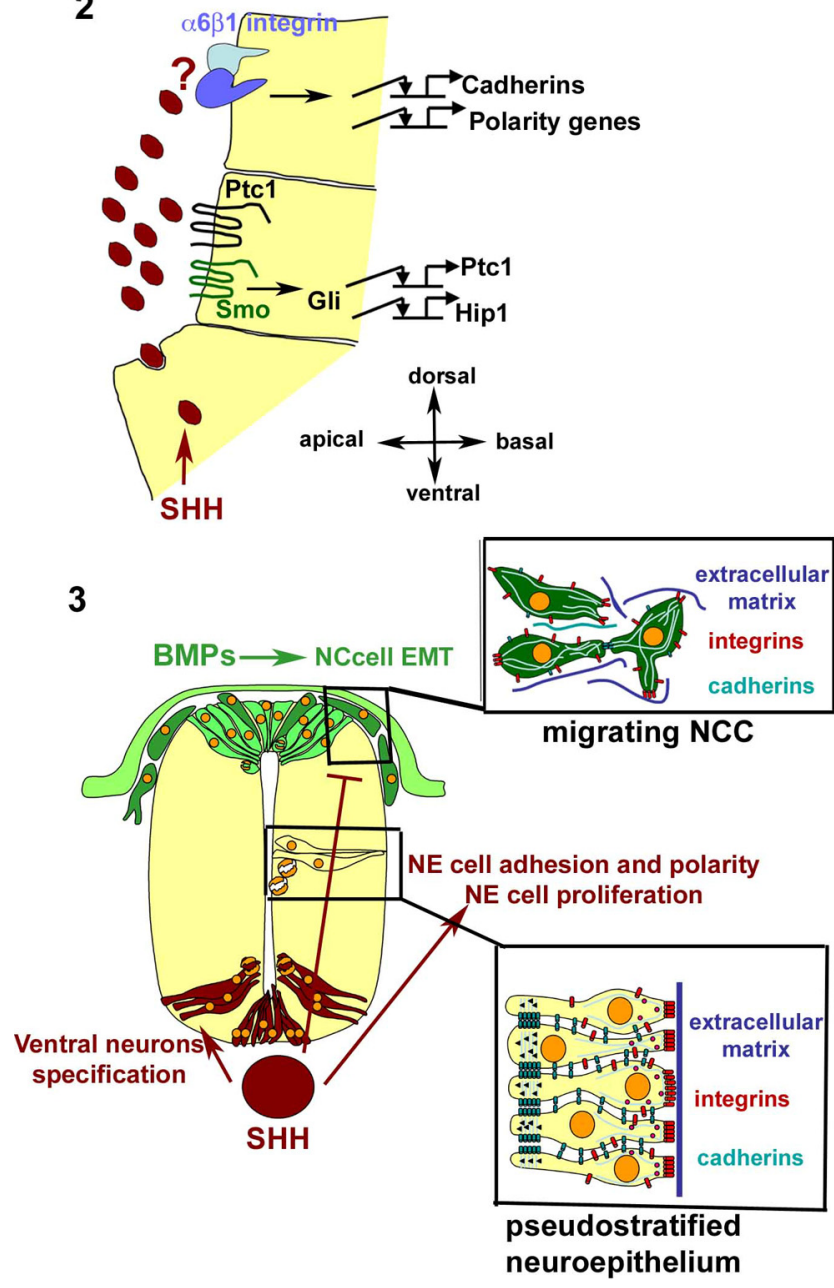

Figure 11. Putative model of control of cell adhesion and polarity by SHH activity. 1, Schematic representation of the caudal neural tube in a 15-18 somite chick embryo. Although NE cells are organized as an epithelium-like structure limited by a basal lamina, they are poorly cohesive and are not fully polarized. Activated $\beta 1$ integrins are uniformally distributed on their entire surface, with no preferential concentration in the basal side. Shh signal produced by the notochord is faint and limited to the floor plate in the ventral neural tube. Dorsally, despite BMP expression in the ectoderm, migration of prospective NC cells is prevented because of Noggin activity. 2, As maturation of the neural tube progresses, SHH release toward the luminal side of ventral NE cells progressively blocks the activation of $\beta 1$ integrins at the apical pole by an as-yet-undefined mechanism independent of the canonical Ptc-Smo-Gli signaling pathway. Inactivation of $\beta 1$ integrins causes upregulation of cadherins and polarity genes, which, in turn, reinforce NE cell-cell adhesion and apicobasal polarity, resulting in the local restriction of functional integrins to the basal side in contact with the extracellular matrix. Increase in Shh activity mediated by the Ptc-Smo-Gli signaling pathway, which induces the graded dorsoventral specification of NE cells, also provokes the feedback upregulation of Ptc1 and Hip1, known to sequester $\mathrm{SHH}$ protein and reduce its range of action. This mechanism could also participate to the progressive attenuation of Shh control on NE cell adhesion and polarity once the pseudostratified aspect of the neuroepithelium is established. 3 , Schematic representation of delamination independently of a NC phenotype but fails to promote migration. Expressing both Snail2 and Ets 1 confers full capacity to migrate (Théveneau et al., 2007), and knocking down Snail2 does not alter NC delamination but results in apoptosis during migration (Cheung et al., 2005; Teng et al., 2008). These observations indicate that NE cell ability to delaminate is not sufficient for adopting $\mathrm{NC}$ features and that, conversely, acquisition of NC identity is not necessary for delamination but is a prerequisite for survival. Intriguingly, $B m p 4$ misexpression in the neural tube does not induce ectopic cell delamination but enlarges the number of migrating NC cells, favoring delamination by recruiting precursors engaged toward a NC phenotype.

Our results reveal an unanticipated control of neural tube morphogenesis by $\mathrm{SHH}$, allowing coordination of NE cell adhesion with proliferation and differentiation. Modifying the level of $\mathrm{SHH}$, its rate of diffusion, or the time of NE cell sensing could account for its different activities to coordinate neural tube growth. This certainly involves cross talk between $\mathrm{SHH}$ signaling and other morphogens involved in neural tube development. Although BMPs have long been considered to be the main antagonistic activity of $\mathrm{SHH}$ signaling in this process, a recent study (AlvarezMedina et al., 2008) has underlined mechanisms generated by Wnt signaling to repress $S h h$ in the neural tube. Interestingly, interactions between Wnt and SHH signaling have been shown at the ligand level, by the observation that glypican-3 regulates reception and endocytosis of both morphogens (Gallet et al., 2008). Additional studies are required to examine whether such connections control NE cell adhesion and migration with proliferation and specification during neural tube morphogenesis.

\section{References}

Afonso C, Henrique D (2006) PAR3 acts as a molecular organizer to define the apical domain of chick neuroepithelial cells. J Cell Sci 119:4293-4304.

Alvarez-Medina R, Cayuso J, Okubo T, Takada S, Martí E (2008) Wnt canonical pathway restricts graded Shh/Gli patterning activity through the regulation of Gli3 expression. Development 135:237-247.

Bajanca F, Luz M, Duxson MJ, Thorsteinsdóttir S (2004) Integrins in the mouse myotome: developmental changes and differences between the epaxial and hypaxial lineage. Dev Dyn 231:402-415.

Bajanca F, Luz M, Raymond K, Martins GG, Sonnenberg A, Tajbakhsh S, Buckingham M, Thorsteinsdóttir S (2006) Integrin alpha6betal-laminin interactions regulate early myotome formation in the mouse embryo. Development 133:1635-1644.

Briscoe J, Novitch BG (2008) Regulatory pathways linking progenitor patterning, cell fates and neurogenesis in the ventral neural tube. Philos Trans R Soc Lond B Biol Sci 363:57-70.

Bronner-Fraser M, Artinger M, Muschler J, Horwitz AF (1992) Developmentally regulated expression of $\alpha 6$ integrin in avian embryos. Development 115:197-211.

Caswell PT, Spence HJ, Parsons M, White DP, Clark K, Cheng KW, Mills GB, Humphries MJ, Messent AJ, Anderson KI, McCaffey MW, Ozanne BW, Norman JC (2007) Rab25 associates with a5b1 integrin to promote invasive migration in 3D microenvironments. Dev Cell 13:496-510.

Cayuso J, Ulloa F, Cox B, Briscoe J, Martí E (2006) The Sonic hedgehog pathway independently controls the patterning, proliferation and survival of neuroepithelial cells by regulating Gli activity. Development 133: $517-528$.

Chamberlain CE, Jeong J, Guo C, Allen BL, McMahon AP (2008) Notochord-derived Shh concentrates in close association with the api-

$\leftarrow$

the rostral neural tube in a 30 somite chick embryo. In addition to its well known control of NE cell specification and proliferation, Shh activity coordinates NE cell adhesion and polarity in such a way that the migration potential of $\mathrm{NE}$ cells is restricted to the most dorsal part of the neural tube. There, on downregulation of Noggin, BMP activity from the ectoderm is released, thereby allowing NC cell delamination and migration. 
cally positioned basal body in neural target cells and forms a dynamic gradient during neural patterning. Development 135:1097-1106.

Charrier JB, Lapointe F, Le Douarin NM, Teillet MA (2001) Anti-apoptotic role of Sonic hedgehog protein at the early stages of nervous system organogenesis. Development 128:4011-4020.

Cheung M, Chaboissier MC, Mynett A, Hirst E, Schedl A, Briscoe J (2005) The transcriptional control of trunk neural crest induction, survival, and delamination. Dev Cell 8:179-192.

Chuang PT, McMahon AP (1999) Vertebrate hedgehog signaling modulated by induction of a hedgehog-binding protein. Nature 397:617-621.

Colas JF, Schoenwolf GC (2001) Towards a cellular and molecular understanding of neurulation. Dev Dyn 221:117-145.

Coles EG, Taneyhill LA, Bronner-Fraser M (2007) A critical role for Cadherin6B in regulating avian neural crest emigration. Dev Biol 312: 533-544.

Cruz MT, Dalgard CL, Ignatius MJ (1997) Functional partitioning of beta1 integrins revealed by activating and inhibitory mAbs. J Cell Sci 110: 2647-2659.

Duband JL (2006) Neural crest delamination and migration: integrating regulations of cell interactions, locomotion, survival and fate. Adv Exp Med Biol 589:45-77.

Duband JL, Delannet M, Monier F (1995) Neural crest cells: strategies to generate lineage diversification in vitro. In: Neural cell culture: a practical approach (Cohen J, Wilkin GP, eds), pp 133-152. Oxford: Oxford UP.

Duband JL, Blavet C, Jarov A, Fournier-Thibault C (2009) Spatio-temporal control of neural epithelial cell migration and epithelium-tomesenchyme transition during neural tube development. Dev Growth Differ 51:25-44.

Fournier-Thibault C, Pourquié O, Rouaud T, Le Douarin NM (1999) BEN/ SC1/DM-GRASP expression during neuromuscular development: a cell adhesion molecule regulated by innervation. J Neurosci 19:1382-1392.

Frisch SM, Screaton RA (2001) Anoikis mechanisms. Curr Opin Cell Biol 13:555-562.

Gallet A, Staccini-Lavenant L, Thérond PP (2008) Cellular trafficking of the glypican Dally-like is required for full-strength Hedgehog signaling and wingless transcytosis. Dev Cell 14:712-725.

Günther T, Struwe M, Aguzzi A, Schughart K (1994) Open brain, a new mouse mutant with severe neural tube defects, shows altered gene expression patterns in the developing spinal cord. Development 120:31193130 .

Han J, Lim CJ, Watanabe N, Soriani A, Ratnikov B, Calderwood DA, PuzonMcLaughlin W, Lafuente EM, Boussiotis VA, Shattil SJ, Ginsberg MH (2006) Reconstructing and deconstructing agonist-induced activation of integrin $\alpha \operatorname{IIb} \beta 3$. Curr Biol 16:1796-1806.

Hervy M, Hoffman L, Beckerle MC (2006) From the membrane to the nucleus and back again: bifunctional focal adhesion proteins. Curr Opin Cell Biol 18:524-532.

Hong E, Brewster R (2006) N-cadherin is required for the polarized cell behaviors that drive neurulation in the zebrafish. Development 133: 3895-3905.

Ingham PW, McMahon AP (2001) Hedgehog signaling in animal development: paradigms and principles. Genes Dev 15:3059-3087.

Jarov A, Williams KP, Ling LE, Koteliansky VE, Duband JL, FournierThibault C (2003) A dual role for Sonic hedgehog in regulating adhesion and differentiation of neuroepithelial cells. Dev Biol 261:520-536.

Jeong J, McMahon AP (2005) Growth and pattern of the mammalian neural tube are governed by partially overlapping feedback activities of the hedgehog antagonists patched 1 and Hhip1. Development 132:143-154.

Kalcheim C, Burstyn-Cohen T (2005) Early stages of neural crest ontogeny: formation and regulation of cell delamination. Int J Dev Biol 49:105-116.

Kida Y, Shiraishi T, Ogura T (2004) Identification of chick and mouse Daam1 and Daam2 genes and their expression patterns in the central nervous system. Brain Res Dev Brain Res 153:143-150.

Kida YS, Sato T, Miyasaka KY, Suto A, Ogura T (2007) Daam1 regulates the endocytosis of EphB during the convergent extension of the zebrafish notochord. Proc Natl Acad Sci U S A 104:6708-6713.

Kinoshita N, Sasai N, Misaki K, Yonemura S (2008) Apical accumulation of rho in the neural plate is important for neural plate cell shape change and neural tube formation. Mol Biol Cell 19:2289-2299.

Lee MS, Kim YB, Lee SY, Kim JG, Kim SH, Ye SK, Lee JW (2006) Integrin signaling and cell spreading mediated by phorbol 12-myristate 13-acetate treatment. J Cell Biochem 99:88-95.

Liem KF Jr, Tremml G, Jessell TM (1997) A role for the roof plate and its resident TGF $\beta$-related proteins in neuronal patterning in the dorsal spinal cord. Cell 91:127-138.

Liu JP, Jessell TM (1998) A role for rhoB in the delamination of neural crest cells from the dorsal neural tube. Development 125:5055-5067.

Marigo V, Tabin CJ (1996) Regulation of patched by Sonic hedgehog in the developing neural tube. Proc Natl Acad Sci U S A 93:9346-9351.

Monier-Gavelle F, Duband JL (1997) Cross-talk between adhesion molecules: control of $\mathrm{N}$-cadherin activity by intracellular signals elicited by $\beta 1$ and $\beta 3$ integrins in migrating neural crest cells. J Cell Biol 137:1663-1681.

Muroyama Y, Fujihara M, Ikeya M, Kondoh H, Takada S (2002) Wnt signaling plays an essential role in neuronal specification of the dorsal spinal cord. Genes Dev 16:548-553.

Nakagawa S, Takeichi M (1995) Neural crest cell-cell adhesion controlled by sequential and subpopulation-specific expression of novel cadherins. Development 121:1321-1332.

Nishimura T, Kaibuchi K (2007) Numb controls integrin endocytosis for directional cell migration with aPKC and PAR-3. Dev Cell 13:15-28.

Sonnenberg A, Modderman PW, Hogervorst F (1988) Laminin receptor on platelets is the integrin VLA-6. Nature 336:487-489.

Stamataki D, Ulloa F, Tsoni SV, Mynett A, Briscoe J (2005) A gradient of Gli activity mediates graded Sonic Hedgehog signaling in the neural tube. Genes Dev 19:626-641.

Taneyhill LA, Coles EG, Bronner-Fraser M (2007) Snail2 directly represses cadherin6B during epithelial-to-mesenchymal transitions of the neural crest. Development 134:1481-1490.

Teng L, Mundell NA, Frist AY, Wang Q, Labosky PA (2008) Requirement for Foxd3 in the maintenance of neural crest progenitors. Development 135:1615-1624

Testaz S, Jarov A, Williams KP, Ling LE, Koteliansky VE, Fournier-Thibault C, Duband JL (2001) Sonic hedgehog restricts adhesion and migration of neural crest cells independently of the Patched-Smoothened-Gli signaling pathway. Proc Natl Acad Sci U S A 98:12521-12526.

Théveneau E, Duband JL, Altabef M (2007) Ets-1 confers cranial features on neural crest delamination. PLoS One 2:e1142.

Tucker GC, Aoyama H, Lipinski M, Tursz T, Thiery JP (1984) Identical reactivity of monoclonal antibodies HNK-1 and NC-1: conservation in vertebrates on cells derived from the neural primordium and on some leukocytes. Cell Differ 14:223-230.

Ulloa F, Briscoe J (2007) Morphogens and the control of cell proliferation and patterning in the spinal cord. Cell Cycle 6:2640-2649.

Ungos JM, Karlstrom RO, Raible DW (2003) Hedgehog signaling is directly required for the development of zebrafish dorsal root ganglia neurons. Development 13:5351-5362.

Van Aelst L, Symons M (2002) Role of Rho family GTPases in epithelial morphogenesis. Genes Dev 16:1032-1054.

Wang LC, Liu ZY, Gambardella L, Delacour A, Shapiro R, Yang J, Sizing I, Rayhorn P, Garber EA, Benjamin CD, Williams KP, Taylor FR, Barrandon Y, Ling L, Burkly LC (2000) Conditional disruption of hedgehog signaling pathway defines its critical role in hair development and regeneration. J Invest Dermatol 114:901-908.

Wilcock AC, Swedlow JR, Storey KG (2007) Mitotic spindle orientation distinguishes stem cell and terminal modes of neuron production in the early spinal cord. Development 134:1943-1954.

Williams KP, Rayhorn P, Chi-Rosso G, Garber EA, Strauch KL, Horan GS, Reilly JO, Baker DP, Taylor FR, Koteliansky V, Pepinsky RB (1999) Functional antagonists of Sonic hedgehog reveal the importance of the N-terminus for activity. J Cell Sci 112:4405-4414.

Witze ES, Litman ES, Argast GM, Moon RT, Ahn NG (2008) Wnt5a control of cell polarity and directional movement by polarized redistribution of adhesion receptors. Science 320:365-369.

Zallen JA (2007) Planar polarity and tissue morphogenesis. Cell 129:10511063. 